\title{
Thirteen years of observations on primary sugars and sugar alcohols over remote Chichijima Island in the western North Pacific
}

\author{
Santosh Kumar Verma ${ }^{1,2}$, Kimitaka Kawamura ${ }^{1, a}$, Jing Chen ${ }^{1, b}$, and Pingqing Fu ${ }^{1, c}$ \\ ${ }^{1}$ Institute of Low Temperature Science, Hokkaido University, N19, W8, Kita-ku, Sapporo 060-0819, Japan \\ ${ }^{2}$ State Forensic Science Laboratory, Home (Police) Department, Government of Chhattisgarh, Raipur 49001, India \\ anow at: Chubu Institute for Advanced Studies, Chubu University, Kasugai 487-8501, Japan \\ ${ }^{b}$ now at: School of Environmental Science and Engineering, Tianjin University, Tianjin 300072, China \\ ${ }^{c}$ now at: Institute of Surface-Earth System Science, Tianjin University, Tianjin 300072, China
}

Correspondence: Kimitaka Kawamura (kkawamura@isc.chubu.ac.jp)

Received: 19 May 2017 - Discussion started: 17 July 2017

Revised: 13 November 2017 - Accepted: 19 November 2017 - Published: 4 January 2018

\begin{abstract}
In order to understand the atmospheric transport of bioaerosols, we conducted long-term observations of primary sugars and sugar alcohols over remote Chichijima Island in the western North Pacific from 2001 to 2013. Our results showed that concentrations of total sugar compounds for 13 years ranged from 1.2 to $310 \mathrm{ng} \mathrm{m}^{-3}$ (average of $46 \pm 49 \mathrm{ng} \mathrm{m}^{-3}$ ). We found that atmospheric circulations significantly affect the seasonal variations of bioaerosol distributions over the western North Pacific. The primary sugars (glucose and fructose) maximized in summer, possibly due to an increased emission of the vegetation products from local vascular plants in Chichijima. We also found higher concentrations of sugar components (arabitol, mannitol, and trehalose) in more recent years during summer and autumn, suggesting an enhanced emission of fungal and microbial species over the island. Sucrose peaked in late winter to early spring, indicating a springtime pollen contribution by long-range atmospheric transport, while elevated concentrations of sucrose in early summer could be explained by longrange transport of soil dust from Southeast Asia to Chichijima. Sucrose and trehalose were found to present increasing trends from 2001 to 2013, while total sugar components did not show any clear trends during the 13-year period. Positive matrix factorization analyses suggested the locally emitted sugar compounds as well as long-range-transported airborne pollen grains, microbes, and fungal spores are the major contributors to total sugar compounds in the Chichijima aerosols. Backward air mass trajectories support the atmo-
\end{abstract}

spheric transport of continental aerosols from the Asian continent during winter and spring over Chichijima.

\section{Introduction}

East Asia has experienced rapid economic development and population growth in the last several decades (Elliot et al., 1997; Jaffe et al., 1999, 2003), whose activities emit organic aerosols and bioaerosols into the atmosphere $(\mathrm{Xu}$ et al., 2011). The atmospheric particles are transported to downwind regions in the Pacific, associated with Asian desert dust from the Taklamakan and Gobi deserts and the Loess Plateau (Duce et al., 1980; Iwasaka et al., 1983; Jaffe et al., 1997; Prospero and Savoie, 1989; Talbot et al., 1997). The transported dust contains bacterial cells, fungal spores, and microbial cells that fall over the Pacific Ocean and its remote islands (Lacey and West, 2006; Mims and Mims, 2003). The microbes associated with bioaerosols significantly affect the natural environment of marine and land ecosystem in downwind regions (Graffin et al., 2003, 2007; Prospero et al., 2005). Long-range atmospheric transport plays a key role in the global distribution of microbes from source regions to receptor sites (Graffin et al., 2001). Fungi and bacteria are often attached to dust particles, which can propagate diseases to human and plants (Brown and Hovmoller, 2002). Therefore, the transported organic aerosols and bioaerosols have been the focus of extensive studies for the past years (Yamaguchi et al., 2012). 
Organic aerosols are composed of a complex mixture of different types of molecules, in which water-soluble organic compounds (WSOCs) are enriched (Graham et al., 2002). WSOCs play an important role in climate change and global radiative forcing by scattering or absorbing light directly or indirectly (Fuzzi et al., 2007). They can act as cloud condensation nuclei (CCN) (Kanakidou et al., 2005; Martin et al., 2010). Sugar compounds (SCs) contribute 13-26 and 63\% of total WSOCs identified in continental and marine aerosol samples, respectively (Simoneit et al., 2004a, b). Yttri et al. (2007) reported that sugars (fructose, glucose, sucrose, trehalose) accounted for 0.6-3.1\% of the WSOCs at urban and suburban sites in Norway. Tominaga et al. (2011) analyzed aerosol samples collected from urban and forest suburban site from Japan and reported that the sugars (arabinose, fructose, galactose, glucose, mannose, rhamnose, and xylose) accounted for 2.1 and $4.5 \%$ of the WSOCs in the fine and coarse mode ranges at Yokohama, respectively, and for 3.0 and $7.2 \%$ at Mt. Oyama, respectively. SCs are directly emitted from biological sources such as fungi, algae, pollen, spores, and bacteria (Carvalho et al., 2003; Wang et al., 2009) and are transported long distances in the atmosphere (Wang et al., 2011). They are also derived from suspended soil particles and associated biota (Rogge et al., 2006; Simoneit et al., 2004b; Wang et al., 2009), and biomass burning (Schmidl et al., 2008; Simoneit et al., 2002).

Primary sugars are emitted from biological sources (Medeiros et al., 2006). Glucose and fructose are emitted from terrestrial plant fruits, pollen, and detritus of vascular plants (Cowie and Hedges, 1984; Speranza et al., 1997). Sucrose is the dominant sugar component in airborne pollen grains and plays a significant role in plant blossoming activity (Bieleski, 1995; Fu et al., 2012; Pacini, 2000). Trehalose is emitted from fungal metabolic activities and resuspension of soil particles and unpaved road dust (Rogge et al., 2007; Simoneit et al., 2004). Sugar alcohols are also emitted from biological sources like fungi and microbes via metabolic activities (Bauer et al., 2008b). Sugar alcohols, i.e., arabitol and mannitol, are tracers for fungal spores (Jia and Fraser, 2011; Yang et al., 2012). Di Filippo et al. (2013) reported that arabitol and mannitol are key sugar components in fungal spores.

Chichijima Island is located in the western North Pacific: an outflow region of Asian dust (Mochida et al., 2003a). It is one of the best remote islands to study the long-range transport of Asian aerosols because local pollutants in Chichijima are insignificant due to low population density and no major sources from industrial or anthropogenic activities (Chen et al., 2013). Kawamura et al. (2003) reported that concentrations of lower molecular weight fatty acids $\left(\mathrm{C}_{12}-\mathrm{C}_{19}\right)$ derived from marine organisms became higher in summer, while those of higher molecular weight fatty acids $\left(\mathrm{C}_{21}-\mathrm{C}_{34}\right)$, n-alkanes $\left(\mathrm{C}_{25}-\mathrm{C}_{35}\right)$, n-alcohols $\left(\mathrm{C}_{20}-\mathrm{C}_{34}\right)$, and dicarboxylic acids $\left(\mathrm{C}_{20}-\mathrm{C}_{28}\right)$ derived from terrestrial higher plants and soil organic matter maximized in winter to spring.

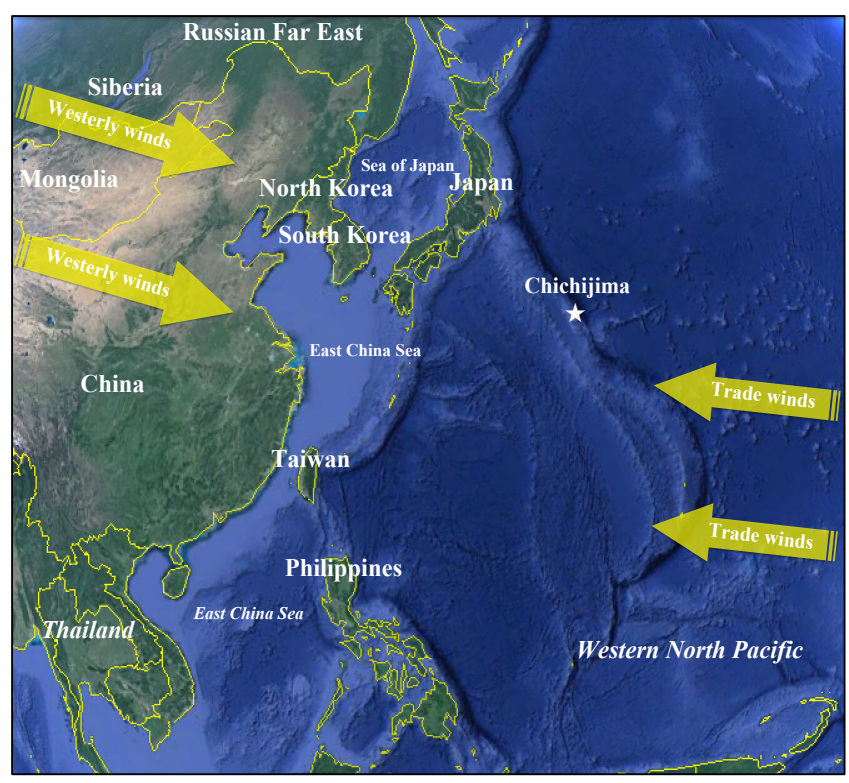

Figure 1. Geographical location of Chichijima Island $\left(27^{\circ} 04^{\prime} \mathrm{N}\right.$, $142^{\circ} 13^{\prime} \mathrm{E} ; 254 \mathrm{~m}$ a.s.1.) in the western North Pacific.

Seasonal variations of low molecular weight $\left(\mathrm{C}_{2}-\mathrm{C}_{10}\right)$ dicarboxylic acids and levoglucosan (biomass burning tracer) have also been reported in Chichijima aerosols by Mochida et al. (2003a) and Mochida et al. (2010), respectively. Although seasonal variation of saccharides was reported in Chen et al. (2013), the observation period is rather short.

Here, we report on a 13-year data set of SCs in remote Chichijima Island. The goal of this study is to characterize seasonal and annual variations of SCs and specify their possible source regions. We will also discuss the potential role of Asian dust in controlling the distributions of bioaerosols over the western North Pacific. The outcomes of this study will improve our understanding of the possible influence of the long-range transport of bioaerosols from the continent to the clean oceanic environment. We will compare the data set of SCs for the periods 1990-1993, 2001-2003, and 2010-2013, which may provide imperative information about decadal changes in the atmospheric conditions over Chichijima. Seasonal source identification by positive matrix factorization (PMF) analysis will also be discussed for the measured SCs.

\section{Materials and methods}

\subsection{Sampling site and meteorological conditions}

Detailed information on the sampling site was reported in Kawamura et al. (2003) and Chen et al. (2013). Briefly, Chichijima Island is located in the western North Pacific $\left(27^{\circ} 04^{\prime} \mathrm{N}, 142^{\circ} 134^{\prime} \mathrm{E}\right), 1000 \mathrm{~km}$ south of Tokyo, Japan, and $2000 \mathrm{~km}$ east of the Asian continent (Fig. 1). The total area 


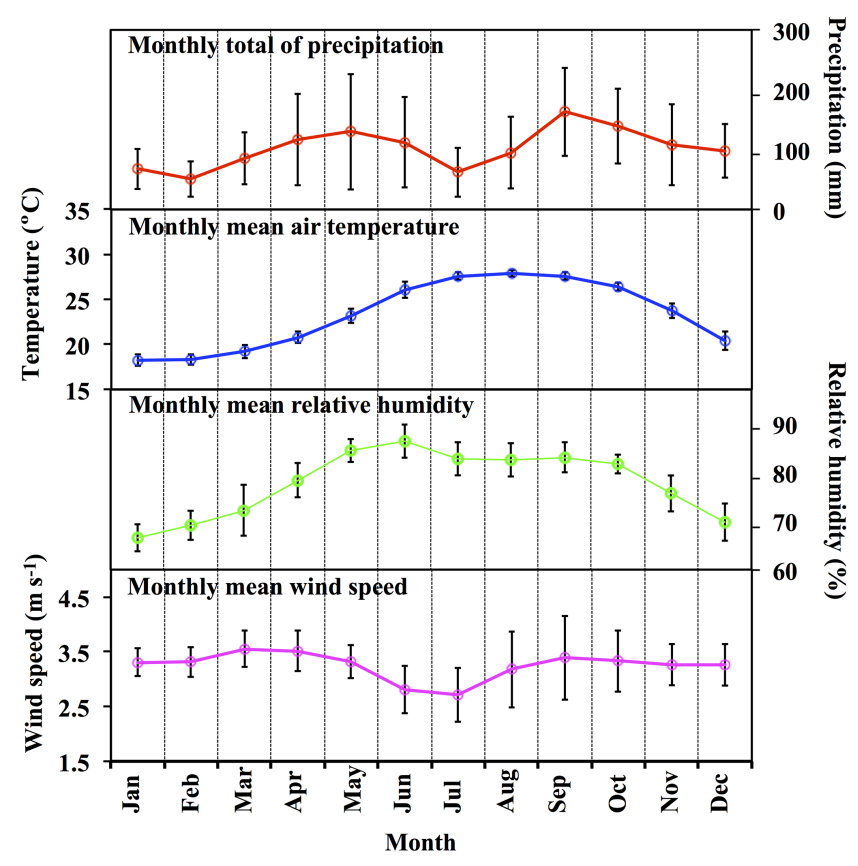

Figure 2. The monthly variation of the meteorological parameters over Chichijima Island during 2001-2013. (The error bars denote the standard deviation.)

of the island is $24 \mathrm{~km}^{2}$ with a population of 2000 (Verma et al., 2015). The climate of Chichijima is classified as subtropical; it is warm to hot (temperature, $7.8-34.1^{\circ} \mathrm{C}$ ) and humid (relative humidity, 66-88\%) all year round.

Figure 2 shows monthly averaged variations in the meteorological parameters of Chichijima during 2001-2013. It receives more precipitation between April and July, and September and October, during the 13-year period. The sampling site is less influenced by the East Asian monsoon in receiving heavy rainfall compared to Northeast Asia. The climate over Chichijima is strongly influenced by the seasonal changes in wind system. In winter and spring, the westerly winds are dominant with the air masses being enriched with Asian dust, industrial pollutants, biomass burning products, organic compounds, and black carbon as well as bioaerosols emitted from East Asia and Eurasia (Fig. 3) (Seinfeld et al., 2004; Simoneit et al., 2004b; Wang et al., 2009). Trade winds are dominant in summer and autumn, which transport clean and pristine marine air masses from the central Pacific to Chichijima (Kawamura et al., 2003; Mochida et al., 2010).

\subsection{Aerosol sampling and chemical analysis}

Details on aerosol sampling and chemical analysis are reported elsewhere (Chen et al., 2013; Mochida et al., 2010). Briefly, total suspended particle (TSP) samples were collected at the Ogasawara Downrange Station of the Japan Aerospace Exploration Agency (JAXA) on Chichijima Island $(254 \mathrm{~m}$ above sea level, a.s.l.). The samples were col- lected on a weekly basis (January 2001 to November 2013) using a high-volume air sampler (Kimoto AS-810A) at a flow rate of $1.0 \mathrm{~m}^{3} \mathrm{~min}^{-1}$ and pre-combusted $\left(450^{\circ} \mathrm{C}\right.$ for $6 \mathrm{~h}$ ) quartz fiber filters $\left(20 \times 25 \mathrm{~cm}\right.$, Pallflex $\left.{ }^{\circledR}\right)$. The filter sample was placed in a pre-combusted glass jar with a Teflon ${ }^{\circledR}$-lined screw cap and stored in a dark freezer room at $-20^{\circ} \mathrm{C}$ prior to analysis in order to inhibit fungal growth. Due to maintenance of the JAXA facility at the sampling site, TSP samples were not collected in November-December 2004 and March-August 2005.

Total 590 aerosol samples were analyzed to determine primary sugars (xylose, fructose, glucose, sucrose, and trehalose) and sugar alcohols (erythritol, arabitol, mannitol, and inositol) during 2001 to 2013. An aliquot $\left(21 \mathrm{~cm}^{2}\right)$ of the filters were extracted three times with a dichloromethane/methanol $(2: 1, v / v)$ mixture using ultrasonic agitation for $10 \mathrm{~min}$. A Pasture pipette packed with quartz wool was used to remove particles and filter debris in the extracts. Filtrates were then concentrated using a rotary evaporator under vacuum and blown down with a stream of pure nitrogen gas. The total extracts were derivatized using $60 \mu \mathrm{L}$ of N,OBis-(trimethylsilyl)trifluoroacetamide (BSTFA) with $1 \%$ trimethylsilyl chloride in the presence of $10 \mu \mathrm{L}$ pyridine in a sealed vial at $70^{\circ} \mathrm{C}$ for $3 \mathrm{~h}$ to convert hydroxyl groups to corresponding trimethylsilyl (TMS) ethers. The derivatized fractions were diluted with $\mathrm{n}$-hexane containing the internal standard of $C_{13} \mathrm{n}$-alkane $\left(1.43 \mathrm{ng} \mu \mathrm{L}^{-1}\right)$, prior to injection to a gas chromatograph-mass spectrometer (GC-MS).

Identification of SCs has been confirmed by the comparison of GC retention times and mass spectra with those of authentic standards as well as literature and library data. SCs were characterized by their common base peak at $\mathrm{m} / \mathrm{z}$ 217 and 204 with specific fragment ions for individual sugars, i.e., $m / z=307$ (arabitol), 205 and 319 (mannitol), 205 (erythritol), 305 and 318 (inositol), 361 (sucrose and trehalose), 191 (glucose), and 437 (fructose). The selected ion peak area and relative response factors determined by injection of authentic standards have been used for the quantification of sugar compounds. Field blank filters were analyzed as a real sample, but no target compounds were detected in the field blanks. The recoveries of the target compounds were better than $90 \%$. Therefore, the data reported here were not corrected for recoveries. Analytical errors of SCs were generally $<15 \%$ based on duplicate analysis. The detection limits of primary sugars and sugar alcohols were $105-557 \mathrm{pg} \mathrm{L}^{-1}$, which corresponds to ambient concentrations of $0.0015-0.0081 \mathrm{ng} \mathrm{m}^{-3}$ under a typical sampling volume of $9000 \mathrm{~m}^{3}$ (Zhu et al., 2015).

The derivatized fractions were introduced into GC-MS using an Agilent model $7890 \mathrm{GC}$ coupled to an Agilent model 5975 mass selective detector (MSD) operated in an electron impact mode at $70 \mathrm{eV}$ and scanned from 40 to $650 \mathrm{Da}$. The GC separation was carried out on a DB-5MS fused silica capillary column ( $30 \mathrm{~m}$ long, $0.25 \mathrm{~mm}$ i.d., $0.25 \mu \mathrm{m}$ film thick- 


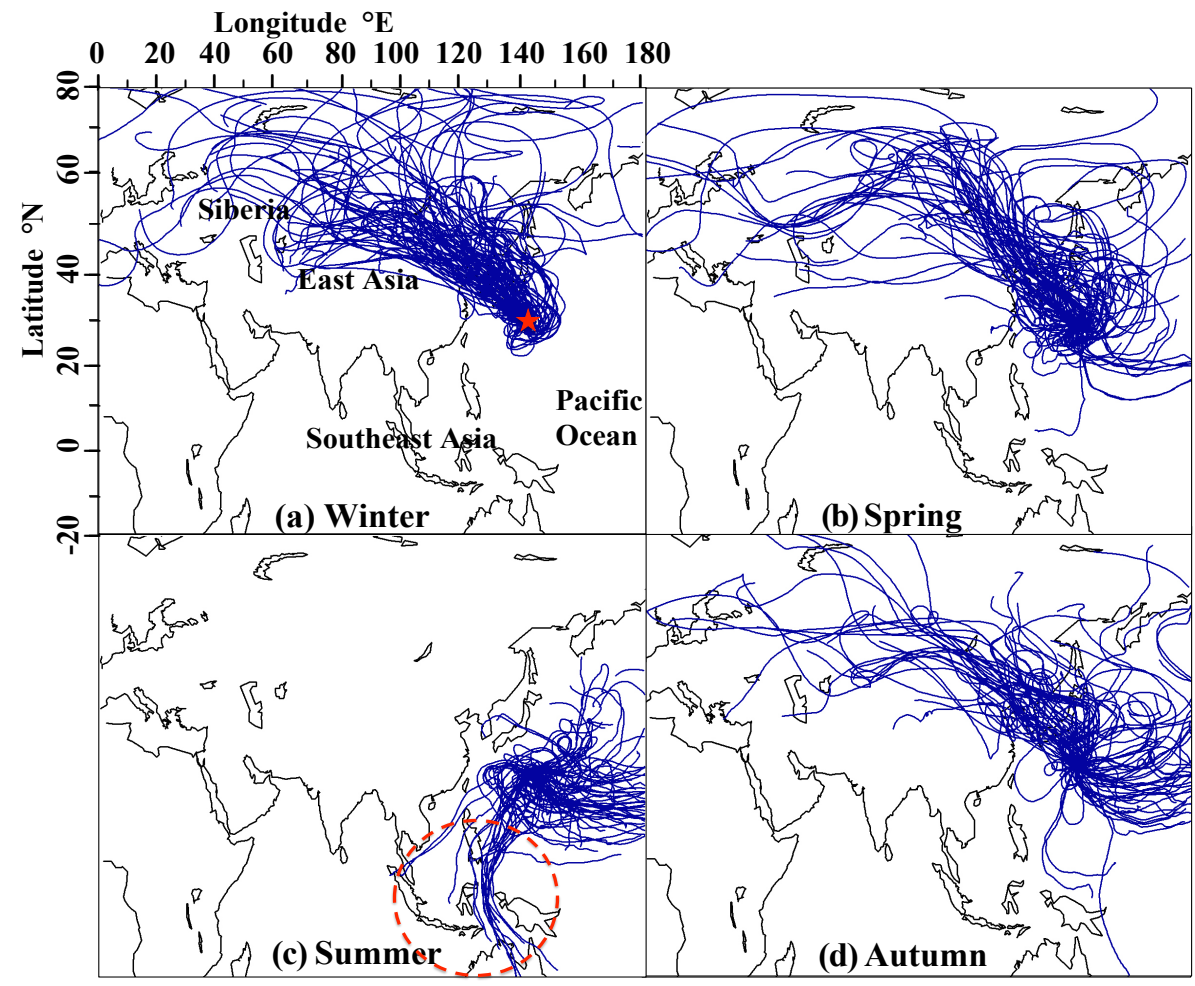

Figure 3. The seasonal 10-day air mass backward trajectories over Chichijima for 2012 (a winter: Dec-Feb, b spring: Mar-May, c summer: Jun-Aug, d autumn: Sep-Nov). The trajectory calculations were performed everyday starting at Chichijima Island.

ness), with a temperature program of $50^{\circ} \mathrm{C}$ for $2 \mathrm{~min}$ at a rate of $15^{\circ} \mathrm{C} \mathrm{min}{ }^{-1}$ from 50 to $120^{\circ} \mathrm{C}$, then from 120 to $305^{\circ} \mathrm{C}$ at a rate of $5^{\circ} \mathrm{C} \mathrm{min}{ }^{-1}$ with a final isotherm hold at $305^{\circ} \mathrm{C}$ for $15 \mathrm{~min}$. The sample was injected on a splitless mode at an injector temperature of $280^{\circ} \mathrm{C}$. GC-MS data were acquired and processed with the Agilent GC/MSD ChemStation software.

\subsection{Backward air mass trajectory analysis}

In order to identify the source regions of sugar compounds in Chichijima aerosols, 10-day backward trajectories were calculated at 00:00 UTC of each sampling period for 13 years using the NOAA Hybrid Single-Particle Lagrangian Integrated Trajectory (http://ready.arl.noaa.gov/HYSPLIT.php) (Fig. 3). The starting height of the trajectories presented in this study is $500 \mathrm{~m}$ a.s.l. We plotted 13-year trajectories for each sampling day but there are no significant year-to-year changes in the atmospheric circulations. Therefore, we presented seasonal trajectories for a recent year (December 2011 to November 2012) in Fig. 3 to understand the seasonal aerosol mass transport from the source regions to Chichijima Island. Backward trajectories significantly supported the long-range transport of air mass under the influence of existing meteorological parameters (Fig. 3). The trajectories clearly show the influences of continental air masses during mid-autumn to mid-spring and of marine air masses during mid-spring to mid-autumn.

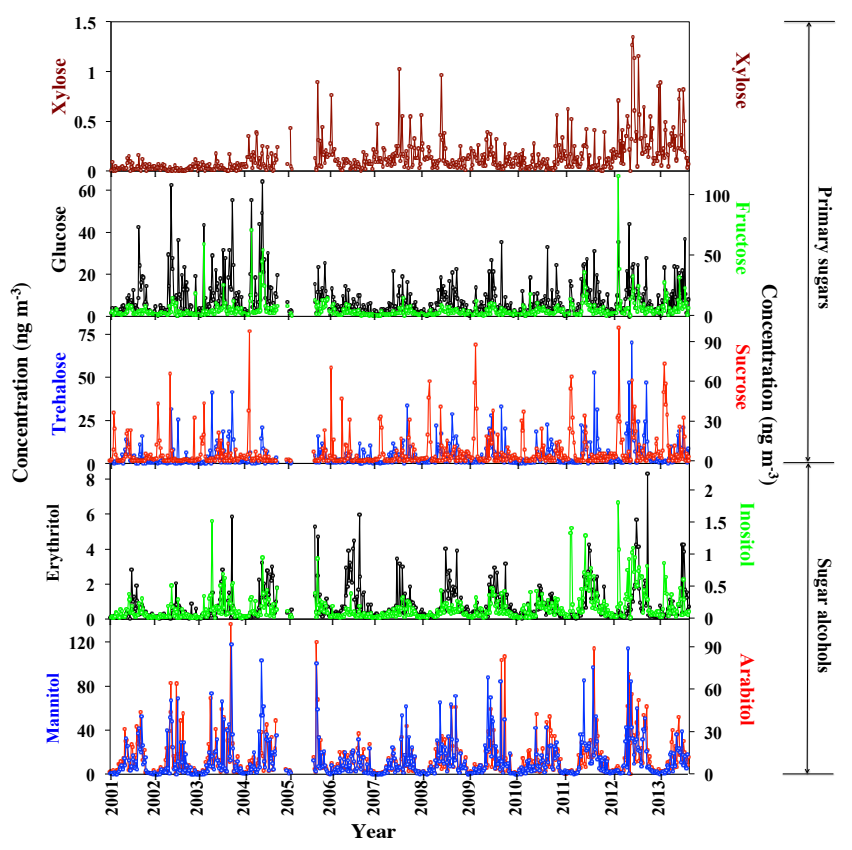

Figure 4. Temporal plots for the concentrations $\left(\mathrm{ng} \mathrm{m}^{-3}\right)$ of sugar compounds in Chichijima aerosol samples collected for 2001-2013 in the western North Pacific. 

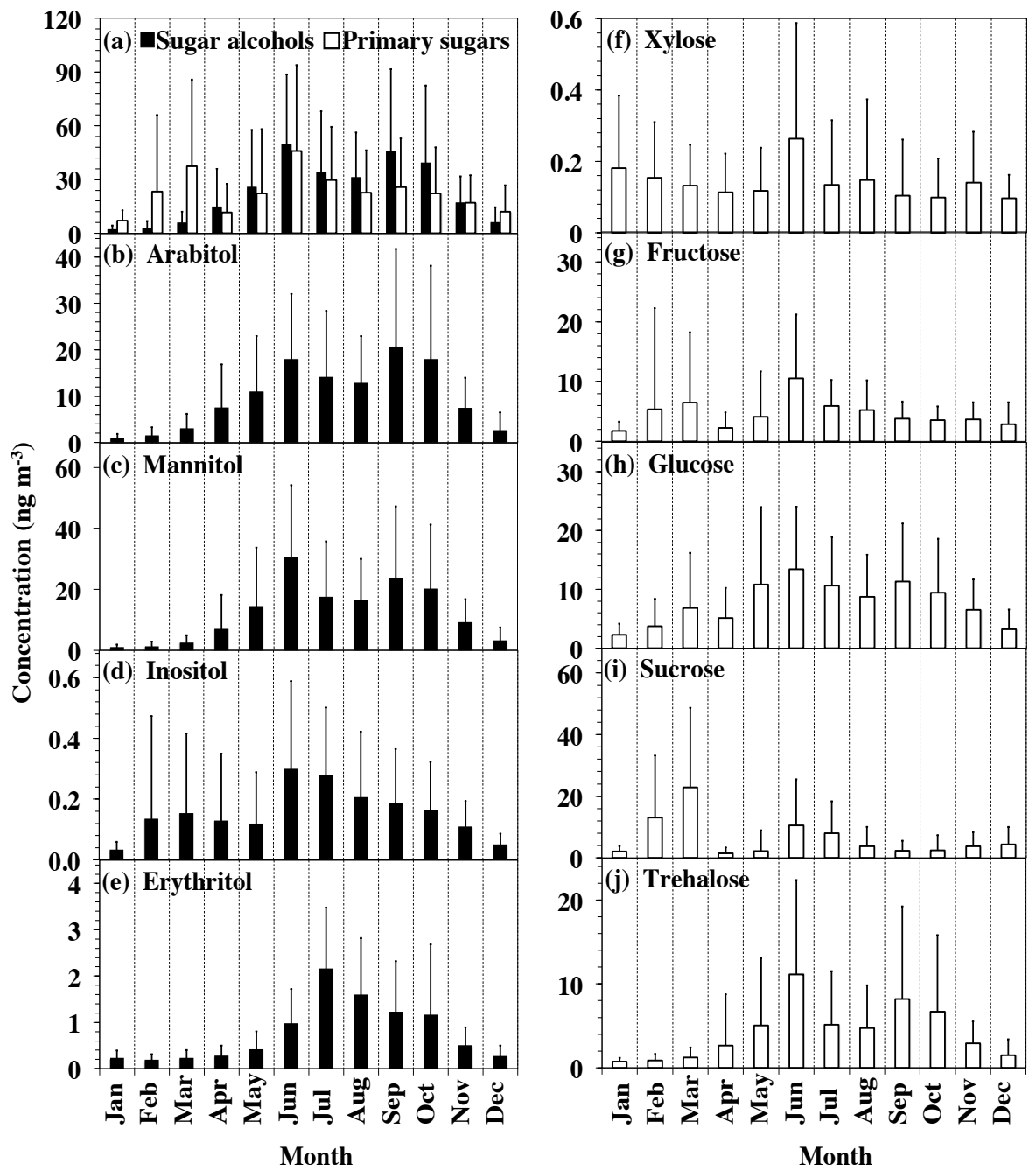

Figure 5. Monthly mean concentrations $\left(\mathrm{ng} \mathrm{m}^{-3}\right)$ of sugar compounds in aerosol samples from Chichijima Island in the western North Pacific during 2001-2013.

\subsection{Positive matrix factorization (PMF) analysis}

Positive matrix factorization (PMF 3.0, Environmental Protection Agency, USA) has been used as a powerful statistical tool that may resolve potential sources contributing to atmospheric levels of particle (given in \%) when appropriate source profiles are not available (Paatero and Tapper, 1994). A few years ago, PMF was used in a precipitation study (Juntto and Paatero, 1994) as well as air pollution and source apportionment studies (Polissar et al., 1999). Recently, it is widely used for air quality and source apportionment (Xie and Berkowitz, 2006). In addition, PMF has been applied to wastewater (Soonthornnonda and Christensen, 2008), lake sediments (Bzdusek et al., 2006), and soils (Lu et al., 2008). One of the main features of PMF results is their quantitative nature; it is possible to obtain the composition of the sources determined by the model.
PMF analysis was performed for quantitative estimation of sources for the collected samples using tracer compounds for primary sugars, sugar alcohols, and anhydrosugars. Based on a given understanding of sugar sources, four-seven factors were examined, and a total of five interpretable factors were characterized by the enrichment of each tracer compound, which reproduced more than $94 \%$ of SCs. Minimal robust and true $\mathrm{Q}$ values of the base run were 3001 and 3413, respectively. Concentrations and percentage of tracers in each factor of bootstrap run were close to those of base run results. The $\mathrm{Q}$ values and factor profiles of $F_{\text {peak }}$ rotation runs showed no significant changes compared with the base run, indicating stable PMF results. The detailed discussions of the determination and application of the PMF are reported in Norris et al. (2008), Paatero et al. (2002), and Zhou et al. (2004). 

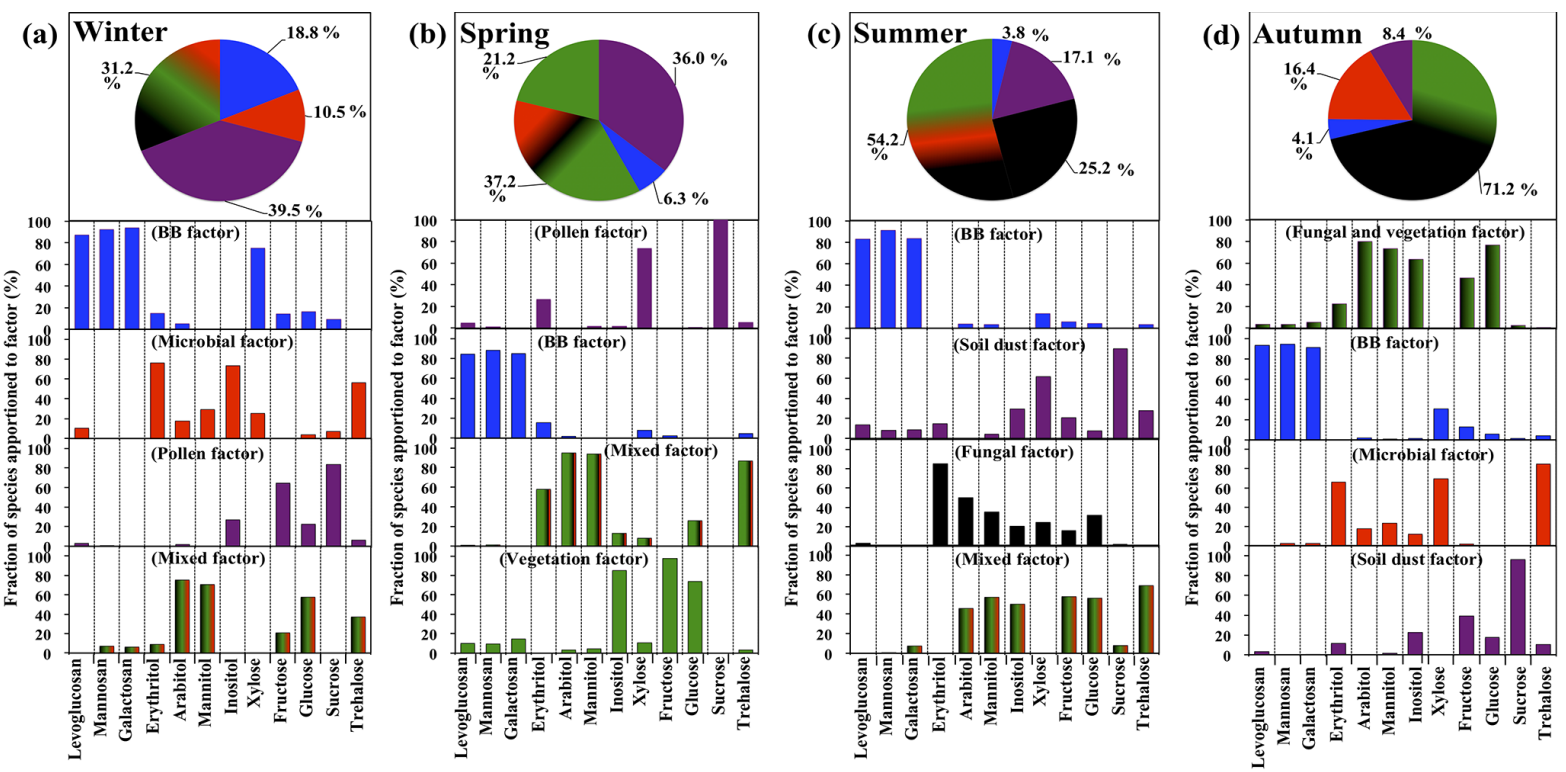

Figure 6. Seasonal source contributions to sugar compounds from various sources based on PMF analyses. (BB - biomass burning; mixed vegetation, fungal, and microbial sources).

In winter and spring, Chichijima Island receives air masses enriched with anthropogenic aerosols from the Asian continent by strong westerly winds, whereas during summer and autumn it receives clean air masses from the Pacific Ocean under the influence of trade winds. The seasonal changes in the atmospheric circulation over Chichijima may have a significant influence on the seasonal distributions of SCs. Therefore, we performed the seasonal PMF analysis on the 13-year sugar data set to better understand the seasonal source profile of individual sugar components. For seasonal PMF analysis, three-five factors were examined, and four factors were determined for each season. We included the data set of anhydrosugars from Verma et al. (2015) for PMF analysis.

\section{Results and discussion}

\subsection{Ambient concentrations of sugar compounds}

Temporal variations of primary sugars and sugar alcohols are shown in Fig. 4. Nine sugar compounds (SCs), including five primary sugars and four sugar alcohols, were detected in the aerosol samples collected from Chichijima Island. The concentrations of total SCs varied from 1.23 to $339 \mathrm{ng} \mathrm{m}^{-3}$ (average of $46.7 \pm 49.5 \mathrm{ng} \mathrm{m}^{-3}$ ) during 2001 to 2013 (Table 1). Concentrations of primary sugars and sugar alcohols were in the range of 0.28 to $176 \mathrm{ng} \mathrm{m}^{-3}\left(23.3 \pm 25.7 \mathrm{ng} \mathrm{m}^{-3}\right)$ and 0.37 to $231 \mathrm{ng} \mathrm{m}^{-3}\left(23.4 \pm 30.8 \mathrm{ng} \mathrm{m}^{-3}\right)$, respectively. The average concentration of primary sugars in Chichijima aerosols is several times lower than that of primary sugars $\left(62.0 \pm 54.9 \mathrm{ng} \mathrm{m}^{-3}\right)$ reported from Cape Hedo, Okinawa, Japan (Zhu et al., 2015), while that of sugar alcohols is equivalent to, or little lower than, that from Cape Hedo $\left(29.5 \pm 35.5 \mathrm{ng} \mathrm{m}^{-3}\right)$.

Interestingly, primary sugars $(49.9 \%)$ and sugar alcohols $(50.1 \%)$ were found to contribute almost equally to total SCs during the entire study period. Mannitol $(26.7 \%)$ and arabitol $(21.4 \%)$ were the main contributors to total SCs, followed by glucose $(16.7 \%)$, sucrose $(13.6 \%)$, fructose $(10.2 \%)$, and trehalose $(9.2 \%)$. Erythritol (1.6\%), inositol $(0.3 \%)$, and xylose $(0.3 \%)$ were also present in the aerosols at lower concentration levels. Temporal plots of individual sugars clearly indicate a large variation of SCs (Fig. 4). This large variation in the concentrations of SCs might be involved with seasonal changes in the atmospheric circulations over the western North Pacific (Kawamura et al., 2003).

\subsubsection{Concentrations of primary sugars in total SCs}

Glucose is the dominant sugar species among primary sugars with the concentration range of 0.05 to $64.3 \mathrm{ng} \mathrm{m}^{-3}$ (average of $\left.7.79 \pm 8.80 \mathrm{ng} \mathrm{m}^{-3}\right)$. Similarly, a wide concentration range of fructose $\left(0.03-115 \mathrm{ng} \mathrm{m}^{-3} ; 4.69 \pm 8.04 \mathrm{ng} \mathrm{m}^{-3}\right)$ was also observed in Chichijima aerosols. Thirteen-year mean concentrations of glucose and fructose were observed to be lower than those $\left(27.2 \mathrm{ng} \mathrm{m}^{-3}\right.$ and $16.4 \mathrm{ng} \mathrm{m}^{-3}$, respectively) reported for the aerosol samples (TSP) from Cape Hedo, Okinawa, Japan (Zhu et al., 2015). Glucose and fructose significantly contribute to total primary sugars (33.5 and $20.17 \%$, respectively) in Chichijima aerosols. Primary sugars are abundant in the fragments of vascular plants in vegetated and forest areas (Medeiros et al., 2006). Pacini et al. (2000) reported that primary sugars are synthesized in leaves during photosynthesis and stored in root, stem, 


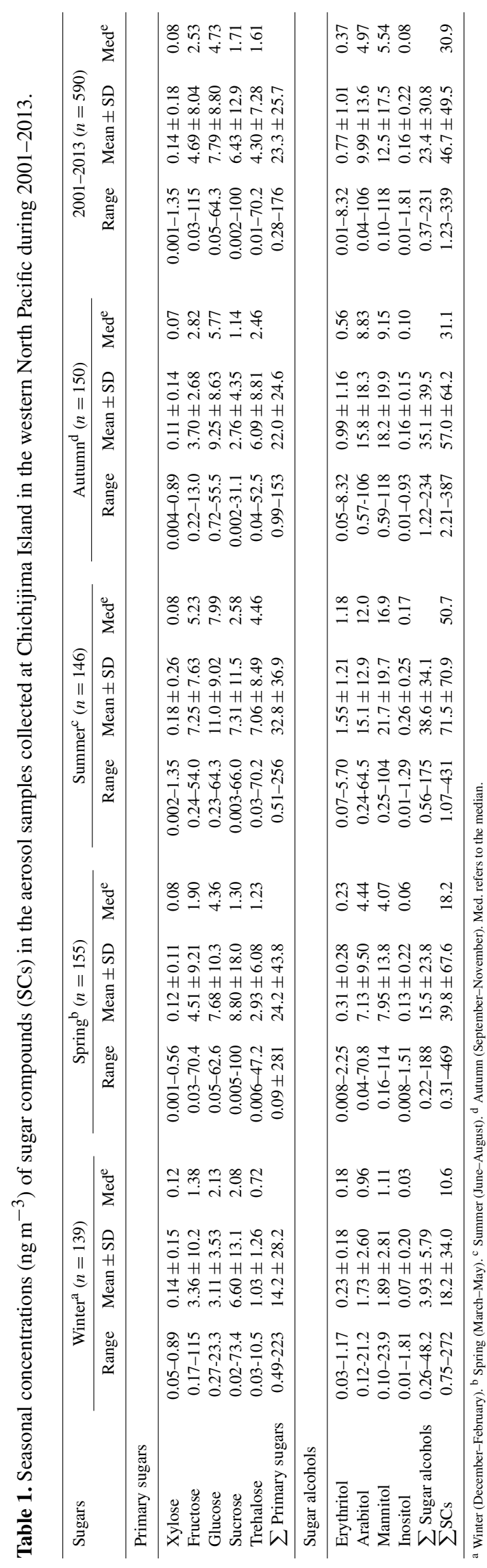

flower, pollen and fruit of growing plants. The nectars and fruits of tropical and subtropical plants also contain glucose and fructose abundantly (Backer et al., 1998). Graham et al. (2002) reported significant amounts of glucose and fructose in pollen, fern spores, and insects in aerosol samples collected from the Amazon forest. Chichijima Island is covered with endemic and vascular plants, which may emit glucose and fructose. Moreover, soil dust (Rogge et al., 2007; Simoneit et al., 2004), lichens (Dahlman et al., 2003), and biomass burning (Medeiros et al., 2006; Nolte et al., 2001) have also been reported as dominate sources of glucose and fructose.

Among all the SCs detected in the Chichijima aerosols, sucrose is the second most abundant sugar species $(0.002$ $100 \mathrm{ng} \mathrm{m}^{-3} ; 6.43 \pm 12.9 \mathrm{ng} \mathrm{m}^{-3}$ ), accounting for $27.3 \%$ of total primary sugars. The average sucrose concentration observed in Chichijima is twice lower than that $\left(13.2 \mathrm{ng} \mathrm{m}^{-3}\right)$ from Cape Hedo, Okinawa, Japan (Zhu et al., 2015). Sucrose is synthesized in plant leaves and circulated by phloem to different plant sections, which is accumulated in root cells as well as developing flower buds (Bieleski, 1995; Jia et al., 2010). Sucrose is a dominant component in airborne pollen grains derived from flowering plants (Bieleski, 1995; Pacini, 2000). Simoneit et al. (2004a, b) reported the presence of sucrose in surface soil and paved road dust. Sucrose was also observed in dry plant materials during the harvesting period (Ma et al., 2009).

Thirteen-year mean concentration of trehalose ranged from 0.01 to $70.2 \mathrm{ng} \mathrm{m}^{-3}\left(4.30 \pm 7.28 \mathrm{ng} \mathrm{m}^{-3}\right)$, whose average concentration accounts for $18.4 \%$ of total primary sugars detected in Chichijima aerosols for 13 years. Microbes (bacterial cell), fungal spores, yeast, algae, invertebrates, and suspended soil dust, as well as plant species, contribute significantly to trehalose in the atmosphere (Elbein, 1974; Graham et al., 2003; Medeiros et al., 2006; Rogge et al., 2007; Simoneit et al., 2004; Wiemken, 1990). Xylose is a less abundant primary sugar, accounting for $0.60 \%$ of total primary sugars observed in Chichijima aerosols. The concentration range of xylose was $0.001-1.35 \mathrm{ng} \mathrm{m}^{-3}$ $\left(0.14 \pm 0.18 \mathrm{ng} \mathrm{m}^{-3}\right)$ during the sampling period of 13 years. Biomass burning activities emit xylose to the atmosphere. Cowie and Hedges (1984) reported that xylose is produced by angiosperm and gymnosperm plants, phytoplankton, and groups of microorganisms. Simoneit et al. (2004a) have reported xylose in soil dust from various locations in the United States and Japan. Wan and Yu (2007) also observed xylose in soils and associated microbiota.

\subsubsection{Concentrations of sugar alcohols in total SCs}

Thirteen-year mean concentrations of arabitol and mannitol were found to be $9.99 \pm 13.6$ and $12.5 \pm 17.5 \mathrm{ng} \mathrm{m}^{-3}$, which contribute to 42.7 and $53.3 \%$ of total sugar alcohols, respectively. The concentration ranges of arabitol (0.04$\left.106 \mathrm{ng} \mathrm{m}^{-3}\right)$ and mannitol $\left(0.10-118 \mathrm{ng} \mathrm{m}^{-3}\right)$ are compara- 


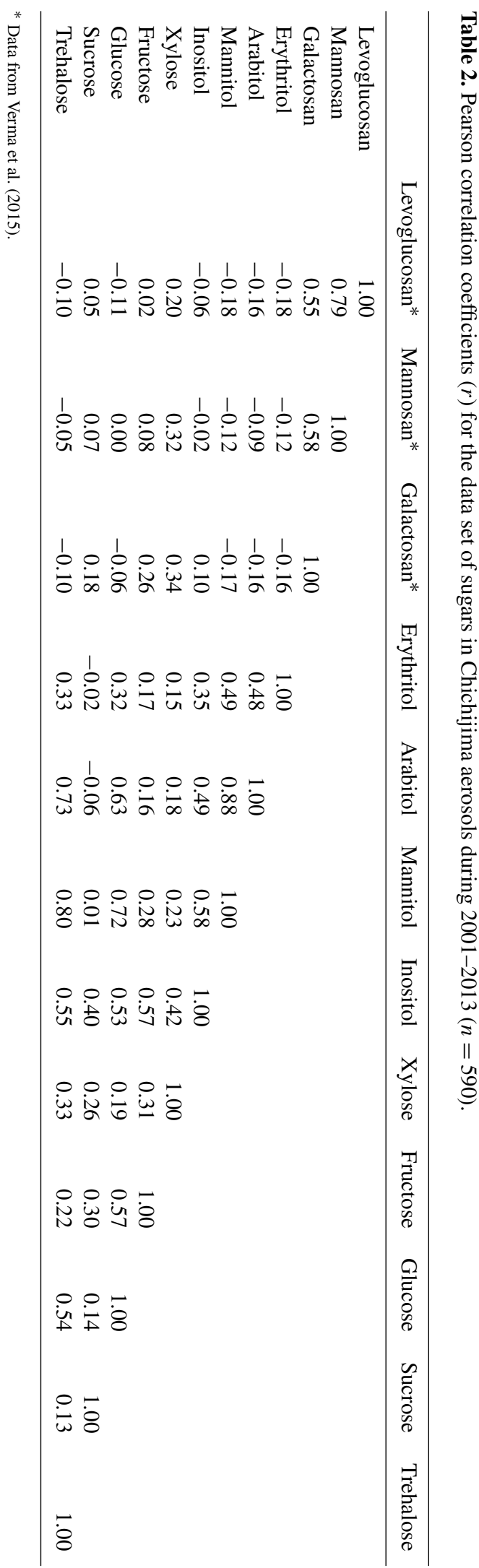

ble to those from the Mediterranean region, Israel (arabitol, $1.85-58.3 \mathrm{ng} \mathrm{m}^{-3}$ and mannitol, $5.57-138 \mathrm{ng} \mathrm{m}^{-3}$ ) (Burshtein et al., 2011). Yttri et al. (2007) also reported that arabitol and mannitol were main contributors of sugar alcohols in aerosol samples collected from different background sites in Norway. Sugar alcohols (arabitol, mannitol) can be used as tracers for various fungal and algal species (Bauer et al., 2008a, b; Pashanska et al., 2002; Zhang et al., 2010). Loos et al. (1994) discussed arabitol and mannitol as potential sources of bacteria and other microbes. High levels of detritus from spring bloom and autumn decomposition have been reported as significant sources of arabitol and mannitol in vegetated regions (Burshtein et al., 2011; Pashynska et al., 2002). Good positive correlations of arabitol $(r=0.63)$ and mannitol $(r=0.72)$ with glucose indicate a vegetation contribution to both sugar alcohols in Chichijima aerosols. Erythritol and inositol are less abundant sugar species, accounting for 3.29 and $0.66 \%$ of total sugar alcohols. Their concentration ranges are $0.01-8.32$ and $0.01-1.81 \mathrm{ng} \mathrm{m}^{-3}$, respectively. Significant positive correlations of both sugar species with arabitol and mannitol indicate similar sources of these SCs in Chichijima aerosols (Table 2).

\subsection{Seasonal variations of total sugar compounds}

Seasonal concentration range, mean, and median values of individual sugars during the study periods of 13 years are presented in Table 1. The concentrations of individual sugars fluctuated extensively from season to season in aerosol samples collected at Chichijima (Figs. 4 and 5a). The seasonally averaged concentrations of total SCs are higher in summer $\left(71.5 \pm 70.9 \mathrm{ng} \mathrm{m}^{-3}\right)$ and autumn $\left(57.0 \pm 64.2 \mathrm{ng} \mathrm{m}^{-3}\right)$ than spring $\left(39.8 \pm 67.6 \mathrm{ng} \mathrm{m}^{-3}\right)$ and winter $\left(18.2 \pm 34.0 \mathrm{ng} \mathrm{m}^{-3}\right)$ over Chichijima Island. Zhu et al. (2015) measured sugar components in aerosol samples collected from Cape Hedo, Okinawa, Japan, and reported 2 to 3 times higher concentrations in summer $\left(136 \mathrm{ng} \mathrm{m}^{-3}\right)$ and spring $\left(133 \mathrm{ng} \mathrm{m}^{-3}\right)$ than autumn $\left(86 \mathrm{ng} \mathrm{m}^{-3}\right)$ and winter $\left(40 \mathrm{ng} \mathrm{m}^{-3}\right)$, whose seasonal trends are similar to Chichijima. Wan and $\mathrm{Wu}$ (2007) reported different seasonal variations, with the highest concentration in autumn $\left(375 \mathrm{ng} \mathrm{m}^{-3}\right)$, followed by winter $\left(292 \mathrm{ng} \mathrm{m}^{-3}\right)$ and spring $\left(84 \mathrm{ng} \mathrm{m}^{-3}\right)$ for continental urban aerosols collected from Hong Kong. These concentrations in Hong Kong are 16 and 6 times higher than those of the remote Chichijima samples for winter and autumn, respectively. Interestingly, the different seasonal trends between the continental urban sites and two islands in the western North Pacific may be associated with different sources and transport pathways between the urban and marine environments.

\subsubsection{Seasonal variations of primary sugars}

Glucose maximized in summer $\left(11.0 \pm 9.02 \mathrm{ng} \mathrm{m}^{-3}\right)$ followed by autumn $\left(9.25 \pm 8.63 \mathrm{ng} \mathrm{m}^{-3}\right), \quad$ spring 
$\left(7.68 \pm 10.3 \mathrm{ng} \mathrm{m}^{-3}\right), \quad$ and winter $\left(3.11 \pm 3.53 \mathrm{ng} \mathrm{m}^{-3}\right)$ (Table 1 and Fig. 5h). Glucose is the most abundant primary sugar in Chichijima aerosols. In winter and spring, Chichijima is influenced by strong westerly winds that deliver the air masses from the Asian continent including Mongolia, the Russian Far East, and North China, where vegetation is active. Consequently, declined concentrations of glucose in winter mean a depressed transport of glucose associated with continental bioaerosols from Asia despite long-range transport of Asian dusts due to strong westerly winds. The local vegetation (vascular plants) in Chichijima Island might be responsible for the enhanced concentration of glucose during growing season (spring and summer) and decaying periods of plant leaves (autumn). Seasonal PMF analysis also supports dominant sources of vegetation for glucose among four factors, which contributed $>5 \%$ for the mixed factor in summer (Fig. 6c), $>80 \%$ for the fungal and vegetation factor in autumn (Fig. 6d), and $>75 \%$ for the vegetation factor in spring (Fig. 6b).

Fructose shows the highest concentrations in summer $\left(7.25 \pm 7.63 \mathrm{ng} \mathrm{m}^{-3}\right)$, followed by spring $\left(4.51 \pm 9.21 \mathrm{ng} \mathrm{m}^{-3}\right), \quad$ autumn $\quad\left(3.70 \pm 2.68 \mathrm{ng} \mathrm{m}^{-3}\right)$, and winter $\left(3.36 \pm 10.2 \mathrm{ng} \mathrm{m}^{-3}\right)$. As shown in Table 2, a significant correlation $(r=0.57)$ was obtained between glucose and fructose. Burshtein et al. (2011) reported similar correlations for both sugar species, suggesting a contribution of glucose and fructose from the local vegetation in summer (Baker et al., 1998; Pacini, 2000). Monthly mean concentrations of fructose show two prominent peaks in February-March and June-July; the latter peak may be due to the local vegetation in Chichijima (Fig. 5g). The fructose peak in February-March may be influenced by airborne pollen grains in the spring bloom of flowering plants. A high concentration of fructose was observed in spring, followed by summer, indicating an input of this sugar compound from pollen grains (Fu et al., 2012). The positive correlation of fructose with sucrose (pollen tracer) supports the similar sources. Seasonal PMF analysis further supports the identical source for fructose and sucrose; that is, among four factors, fructose contributes $>70$ and $>60 \%$ for pollen factor in spring (Fig. 6b) and winter (Fig. 6a), respectively.

Seasonal mean concentrations of trehalose showed a maximum in summer $\left(7.06 \pm 8.49 \mathrm{ng} \mathrm{m}^{-3}\right)$, followed by autumn $\left(6.09 \pm 8.81 \mathrm{ng} \mathrm{m}^{-3}\right)$, spring $\left(2.93 \pm 6.08 \mathrm{ng} \mathrm{m}^{-3}\right)$, and winter $\left(1.03 \pm 1.26 \mathrm{ng} \mathrm{m}^{-3}\right)$ (Table 1$)$. Monthly mean concentrations of SCs for 13 years show that concentrations of trehalose are higher during June to October (Fig. 5j). Ma et al. (2009) reported higher concentrations of trehalose at the urban site of Guangzhou, China, during summer and autumn. Similarly, Wan and Wu (2007) reported a similar autumn maximum in Hong Kong. On the other hand, different seasonal trends of trehalose were reported for the aerosol samples (TSP) collected in the United States (Medeiros et al., 2006), China (Wang et al., 2011), Australia (Hackl et al., 2000), and Gosan, Jeju Island, in the western North Pacific
Rim (Fu et al., 2012). In the above studies, the highest concentrations of trehalose were reported in early spring due to the resuspension of soil particles during agricultural practice. Hackl et al. (2000) also obtained abundant trehalose in spring, and they proposed that trehalose can be used as a tracer of soil dust emission to the atmosphere. However, we did not detect a spring peak of trehalose in Chichijima aerosols, suggesting that soil dust contribution of trehalose over Chichijima is insignificant via long-range atmospheric transport. Seasonal PMF analysis for autumn showed that more than $85 \%$ of trehalose was contributed by the microbial factor among the four factors (Fig. 6d). An indirect contribution of trehalose from soil dust will be discussed later.

The seasonal mean concentrations of sucrose are almost equal during spring $\left(8.80 \pm 18.0 \mathrm{ng} \mathrm{m}^{-3}\right)$, summer $\left(7.31 \pm 11.5 \mathrm{ng} \mathrm{m}^{-3}\right)$, and winter $\left(6.60 \pm 13.1 \mathrm{ng} \mathrm{m}^{-3}\right)$, excluding autumn $\left(2.76 \pm 4.35 \mathrm{ng} \mathrm{m}^{-3}\right)$ (Table 1). The similar seasonal distributions suggest multiple sources of sucrose in Chichijima aerosols. Monthly mean concentrations of sucrose show two peaks during February-March and June-July (Fig. 5i). The March peak of sucrose was reported in the forest area of Sapporo, Japan, to be 3 to 7 times more abundant than other months due to springtime pollen emissions (Miyazaki et al., 2012). Fu et al. (2012) analyzed pollen samples from different plant species (white birch, Chinese willow, Peking willow) for SCs and found the highest concentrations of sucrose followed by fructose and glucose in pollen. The pollen emissions from developing buds of plants may be the reason for the increased concentration of sucrose and fructose in February and March over Chichijima Island in the western North Pacific. Seasonal PMF analysis shows that sucrose contributed $100 \%$ in spring and $>80 \%$ in winter, suggesting a significant pollen contribution for sucrose in those seasons (Fig. 6a and b).

However, the possibilities of pollen transport from East Asia to Chichijima cannot be excluded because pollen can travel long distances with springtime high-speed winds by westerlies (Rousseau et al., 2006). The pollen grains emitted from flowering boreal forest in China, Mongolia, Siberia, and the Russian Far East could significantly be delivered to the western North Pacific during spring, which may result in the contribution of sucrose and fructose to Chichijima aerosols. Recent studies have discussed the long-range transport of airborne pollen from North America to Greenland in spring (Rousseau et al., 2008). Lorenzo et al. (2006) reported the long-range transport of airborne allergenic pollen to central Italy. Makra et al. (2010) reported the long-range transport of airborne pollen in three European cities by applying three-dimensional clustering of backward trajectories. Several studies also discussed the long-range transport of pollen to remote Arctic regions (Andrews et al., 1980; Bourgeois et al., 2001; Campbell et al., 1999; Hicks et al., 2001; Hjelmroos and Franzen, 1994; Rousseau et al., 2004).

These observations may support that westerly winds have delivered pollen grains from the Asian continent, including 

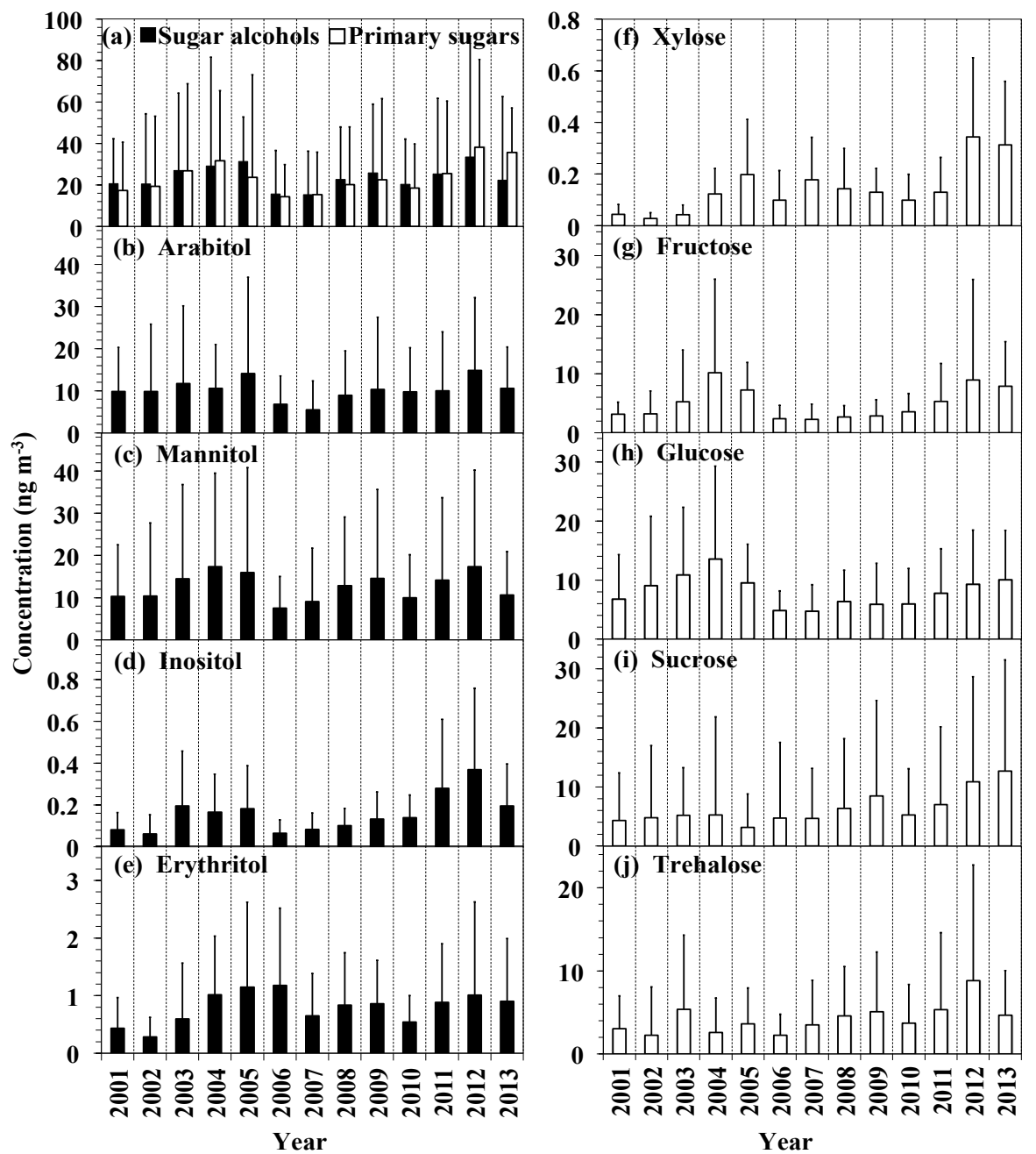

Figure 7. Annual mean concentrations $\left(\mathrm{ng} \mathrm{m}^{-3}\right)$ of sugar compounds in aerosol samples collected from Chichijima Island in the western North Pacific during 2001-2013.

Mongolia, Siberia, and the Russian Far East, to Chichijima Island in spring. Using a box model and typical settling velocity of pollen $\left(3 \mathrm{~cm} \mathrm{~s}^{-1}\right)$ with a grain size of $30 \mu \mathrm{m}$ in diameter (Sosnoskie et al., 2009), we estimated the lifetime of pollen grains to be $9.3 \mathrm{~h}$ in the atmospheric marine boundary layer (height of $1 \mathrm{~km}$ above the ocean surface). The settling velocity of the pollen is ca. 20 times larger than that of typical marine aerosols (Slinn and Slinn, 1980). Because pollen grain sizes range from $10 \mu \mathrm{m}$ to $100 \mu \mathrm{m}$ in diameter, the lifetime of pollen may have a large uncertainty. If pollen can be largely transported in the free troposphere (e.g., $5 \mathrm{~km}$ high) to the North Pacific from the Asian continent, then the lifetime of typical pollen grains would increase up to 2 days. These calculations for the lifetime of pollen grains further support their long-range atmospheric transport from the Asian continent over the western North Pacific. Based on backward air mass trajectories (Fig. 3), we can roughly estimate the transport time from East Asia to the Chichijima site to be $2-4$ days in winter and spring. It is also of interest to note that pollen can rupture under conditions of high relative humidity (RH) (Hader et al., 2014; Miguel et al., 2006; Wright et al., 2014), which leads to smaller particles with longer residence time in the atmosphere.

In addition, the tilling process after wheat crop harvesting in farmland causes an enhanced exposure of wheat root associated with soil particles to the atmosphere. China, India, and the United States are the three largest countries for wheat production in the world. In China and India there are two seasons (spring and winter) for wheat crops; winter wheat is harvested from mid-May to mid-July. During those periods (early summer), Chichijima Island is highly influenced by trade winds (Fig. 3). However, air mass trajectories clearly show the occasional atmospheric transport from Southeast Asia to Chichijima in summer (Pavuluri et al., 2010). PMF results of sucrose for summer (Fig. 6c) and autumn (Fig. 6d) account for $>85$ and $>90 \%$, respectively, for the soil dust 
factor among the four source factors, suggesting an additional source of soil dust for sucrose in Chichijima aerosols (Simoneit et al., 2004). The elevated sucrose concentrations in June and July (summer; non-flowering season) suggest the long-range transport of sucrose associated with soil particles under the influence of occasional air mass transport from Southeast Asia in summer (Fig. 3).

Xylose was found to be the least abundant sugar compound in the aerosol samples. The maximum concentration of xylose $\left(1.35 \mathrm{ng} \mathrm{m}^{-3}\right)$ was found in summer, whereas the minimum concentration $\left(0.001 \mathrm{ng} \mathrm{m}^{-3}\right)$ was found in spring (Table 1). Summer mean concentration $\left(0.18 \pm 0.26 \mathrm{ng} \mathrm{m}^{-3}\right)$ was highest (Table 1). The PMF analyses showed that xylose contributed $>75 \%$ for BB factor in winter (Fig. 6a) and $>70 \%$ in autumn (Fig. 6d) for the microbial factor. These results suggest different sources and seasons for xylose, i.e., biomass burning in winter (Sullivian et al., 2011) and groups of microorganisms in summer (Cowie and Hedges, 1984).

\subsubsection{Seasonal variations of sugar alcohols}

The seasonal mean concentrations of arabitol and mannitol are higher in summer and autumn than spring and winter (Table 1). The concentrations of arabitol are equally distributed between summer $\left(15.1 \pm 12.9 \mathrm{ng} \mathrm{m}^{-3}\right)$ and autumn $\left(15.8 \pm 18.3 \mathrm{ng} \mathrm{m}^{-3}\right)$, with lower levels in spring $\left(7.13 \pm 9.50 \mathrm{ng} \mathrm{m}^{-3}\right)$ and winter $\left(1.73 \pm 2.60 \mathrm{ng} \mathrm{m}^{-3}\right)$. Mannitol maximized in summer $\left(21.7 \pm 19.7 \mathrm{ng} \mathrm{m}^{-3}\right)$, followed by autumn $\left(18.2 \pm 19.9 \mathrm{ng} \mathrm{m}^{-3}\right)$, spring $\left(7.95 \pm 13.8 \mathrm{ng} \mathrm{m}^{-3}\right)$, and winter $\left(1.89 \pm 2.81 \mathrm{ng} \mathrm{m}^{-3}\right)$. Arabitol and mannitol strongly co-varied throughout the study period. As depicted in 13-year monthly mean concentrations of total SCs (Fig. 5b, c), we found elevated concentrations of sugar alcohols from May to October. Similar seasonal trends were reported for the aerosol samples collected from Gosan, Jeju Island, in the western North Pacific Rim (Fu et al., 2012) and urban aerosol samples from Ghent, Belgium (Pashynska et al., 2002). In the above studies, higher relative abundances of arabitol and mannitol in total sugar alcohols were reported during late summer to autumn. The higher concentration of arabitol in autumn was also reported for aerosol samples from the Mediterranean region in Israel (Burshtein et al., 2011). Erythritol and inositol showed a similar seasonal trend, but their concentrations are lower than the former two sugar species.

Sugar alcohols are emitted to the atmosphere from a variety of bacteria and a few green algal lichens and fungi (Dahlman et al., 2003; Filippo et al., 2013). Arabitol and mannitol are abundant in fungal spores (Lewis and Smith, 1967; Yttri et al., 2007). Arabitol ( $r=0.73)$ and mannitol ( $r=0.80)$ showed a strong co-variance with trehalose, suggesting identical sources of sugar species in Chichijima. The PMF analysis showed that the fungal factor and the mixed factor (fungal, vegetation, and microbial) accounted for 25 and $54.2 \%$ of total SCs observed in summer, respectively
(Fig. 6c). In autumn, the fungal and vegetation factor contributed $71 \%$ of total SCs detected in Chichijima aerosols (Fig. 6c). In winter (Fig. 6a) and spring (Fig. 6b), the fungal and vegetation factor and the mixed factor account for 31.2 and $37.2 \%$ of total SCs, respectively. This is reasonable because fungal and microbial activities are lower during winter and spring as compared to summer and autumn. The meteorological factors such as RH and temperature significantly affect fungal and bacterial activity (Kim and Xiao, 2005; Malik and Singh, 2004). Higher RH and temperature are crucial in increasing fungal and bacterial growth (Sharma and Razak, 2003). Their maximum growth was observed under the condition of 92-100\% RH (Ibrahim et al., 2011). Higher concentrations of arabitol and mannitol in summer and autumn may be caused by the increased fungal and bacterial activities in Chichijima Island.

Several studies have described the occurrence of fungi in the marine environment (Kohlmeyer and Kohlmeyer, 1991). The fungal species eject spores from hard materials like coral and sand grains. Some fungi also eject spores from woods associated with sand in summer and autumn when higher ambient temperature and $\mathrm{RH}$ are available (Jones and Mitchell, 1996). Marine fungal growths are observed on several mediums of substrates such as wood, sediments, muds, soil, sand, algae, corals, decaying leaves of mangroves, and living animals in the marine environment (Bremer, 1995; Nagakiri et al., 1996). Although the above-mentioned studies have claimed the occurrence and growth of marine fungi on several mediums of substrates, the knowledge of the role of marine fungi in sediments and decaying dead animals is still insufficient due to a lack of an appropriate data set. It is still unclear whether these fungi are active in sediments (Hyde et al., 1998). Therefore, due to the inadequate data set, we doubt the marine contribution of sugar alcohols (arabitol, mannitol) to Chichijima aerosols.

Thirteen-year monthly mean concentrations of SCs clearly show slightly decreased concentrations of arabitol, mannitol, and erythritol in July and August; a similar trend was observed for trehalose (Fig. 5b, c, e, j). These sugar compounds are derived from the microbial activities in source regions. The 13-year precipitation record over Chichijima Island shows that precipitation was lower in July and August (Fig. 2). The lower precipitation amount decreases the $\mathrm{RH}$ (Fig. 2) and thus depresses the fungal and microbial activities. The lower precipitation also suppresses the moisture contents in the surface soil of Chichijima, which should result in a significant decline of local fungal and other microbial activities on the ground of Chichijima Island. Decreased precipitation might be a possible reason for the lower concentrations of arabitol, mannitol, and trehalose in July and August. 


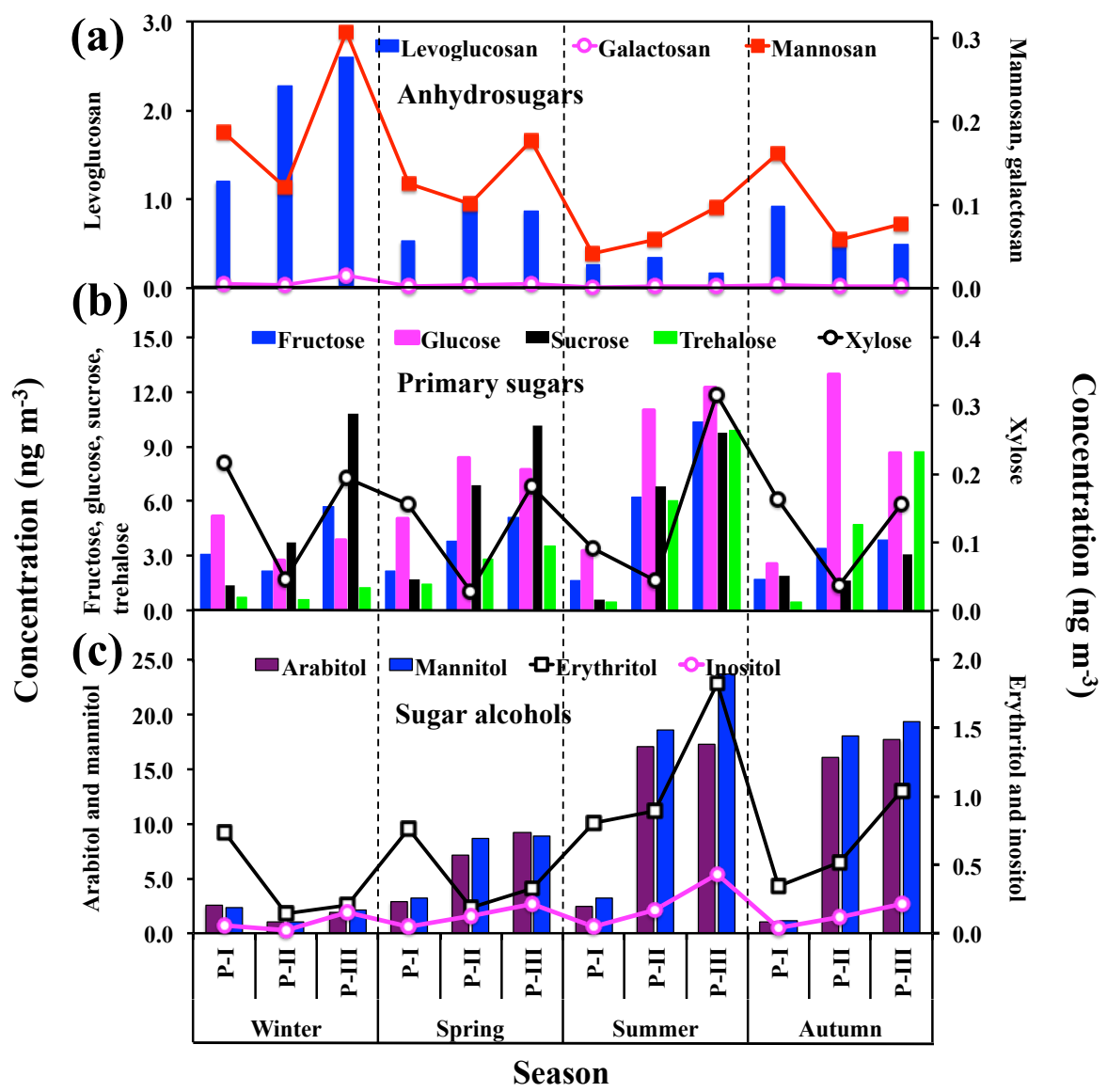

Figure 8. The seasonal concentrations of anhydrosugars (biomass burning tracers), primary sugars, and sugar alcohols measured in Chichijima aerosols during three periods, i.e., P-I (1990-1993), P-II (2001-2003), and P-III (2010-2013).

\subsection{Annual variations and decadal comparisons of SCs}

The annual variations in the concentrations of primary sugars and sugar alcohols are shown in Fig. 7a. The annual mean concentrations of total SCs varied randomly during 2001 to 2013. As shown in Fig. 7i, j, f, and d, concentrations of sucrose, trehalose, xylose, and inositol increase from 2001 to 2013 in Chichijima aerosols. Similarly, arabitol (Fig. 7b), glucose (Fig. 7h), and fructose (Fig. 7g) show clear increasing trends from 2006 to 2013 whereas mannitol (Fig. 7c) and erythritol (Fig. 7e) show a random trend. Here, we compare the data set of SCs for the periods of 1990-1993 (Period, PI) with the current observations from 2001 to 2003 (P-II) and 2010 to 2013 (P-III) (Table 3) (Fig. 8a-c).

The comparison for three periods indicates that concentrations of anhydrosugars are highest in winter, followed by autumn. Their concentrations significantly increased from P-I to P-II/P-III (Fig. 8a). Detailed discussions on anhydrosugars were reported in Verma et al. (2015). Here, we refer to the data set of anhydrosugars for the decadal comparison with SCs. Interestingly, biomass burning tracers (BB tracers; levoglucosan, mannosan, and galactosan) showed a signif- icant difference in the decadal trends among three periods (i.e., P-I, P-II, and P-III) during winter and autumn. In winter, BB tracers showed an increasing trend from P-I to P-III (Fig. 8a). Biomass burning is common in winter for house heating (Simoneit et al., 2004a); thus it is obvious that there are more biomass burning activities when ambient temperature is lower. Westerly winds abundantly transport biomass burning products over Chichijima Island in the western North Pacific with air masses derived from East Asia, Siberia, Mongolia, and the Russian Far East during winter (Bendle et al., 2007; Simoneit and Elias, 2010; Verma et al., 2015). In contrast, BB tracers in autumn show an opposite trend (i.e., higher concentrations in P-I followed by P-II and P-III) compared to those in winter (Fig. 8a).

The difference in the concentrations of anhydrosugars in winter and autumn during P-I is insignificant, while the concentrations are 3 and 5 times higher in winter than autumn for P-II and P-III, respectively. This seasonal shifting in the concentrations of anhydrosugars may be attributable to the changes in the strength of both westerly and trade wind systems from mid-autumn to early winter among three periods (Chen et al., 2013). In contrast, the concentrations of primary 


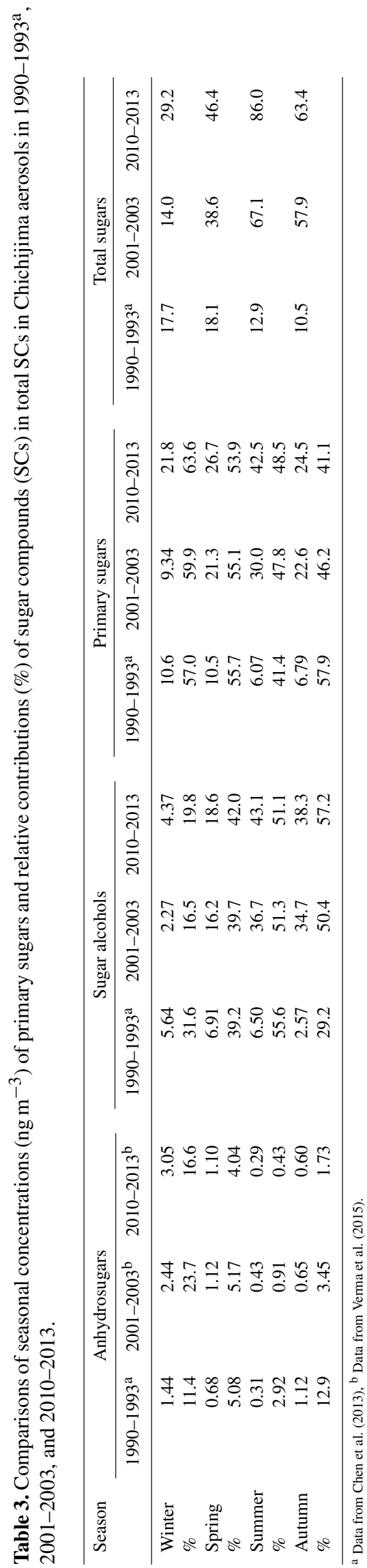

sugars were 2 to 7 times higher during P-II and P-III than the P-I period in summer and autumn (Fig. 8b). PMF analysis showed that local emissions from vegetation are an important contributor for primary sugars (glucose, fructose, and sucrose). Therefore, a drastic increase in the concentrations of primary sugars in summer and autumn for P-II and P-III compared to P-I may be caused by an increased emission of primary sugars by local vegetation under the influence of meteorological conditions in the western North Pacific. However, a possible soil dust contribution of primary sugar (sucrose) associated with an occasional air mass transport from Southeast Asia cannot be excluded.

Similar to primary sugars, a drastic increase in the concentrations of sugar alcohols was observed for P-II and P-III compared to the P-I period (Fig. 8c). The concentrations of sugar alcohols in P-II and P-III are 6 to 19 times higher than those of P-I in summer and autumn (Table 3; Fig. 8c). Arabitol and mannitol are key sugar alcohols and are reported as fungal and microbial tracers, which contribute significantly to total SCs (Bauer et al., 2008b; Lewis and Smith, 1967; Zhang et al., 2010). Microbes such as fungi and bacteria are significantly increasing in Asian and European countries (Yamaguchi et al., 2012). They are largely transported towards downwind regions in the Pacific Ocean from the Asian continent in winter and spring under the influence of strong westerlies (Griffin et al., 2001, 2003; Griffin, 2007; Hua et al., 2007; Uno et al., 2009) and settle through wet and dry deposition in the western North Pacific according to air mass trajectories (Fig. 3).

Hirst et al. (1967) studied the lifetime of fungal spores and the long-range transport of spores. They reported that the fungal spores are between 2 and $200 \mu \mathrm{m}$ in diameter (mostly 5 to $30 \mu \mathrm{m}$ ) and have a settling velocity of between 0.05 and $3.0 \mathrm{~cm} \mathrm{~s}^{-1}$ with a mode of less than $1 \mathrm{~cm} \mathrm{~s}^{-1}$, and that different fungal spores vary significantly in shape and ornamentation. This study suggested the possibilities of long-range transport of fungal spores. Jeon et al. (2011) and Yamaguchi et al. (2012) have analyzed aerosol samples collected during the Asian dust event over the Sea of Japan, and they identified similar groups of microbes (bacterial cells) transported from the source regions of Asian dust. Consequently, bacteria and fungi associated with bioaerosols grow extensively during summer and autumn, when the climate conditions are favorable (i.e., higher RH and temperature) for their metabolic activities (Morris et al., 2004). Accordingly, an increased transport of bioaerosols for the last decade may have caused a drastic increase in the concentrations of sugar alcohols during P-II and P-III compared to the P-I period over the western North Pacific.

\subsection{Source apportionment of SCs}

To investigate the source apportionment of sugar components, the data sets of Chichijima aerosols were subjected to positive matrix factorization (PMF) analysis. Based on the 


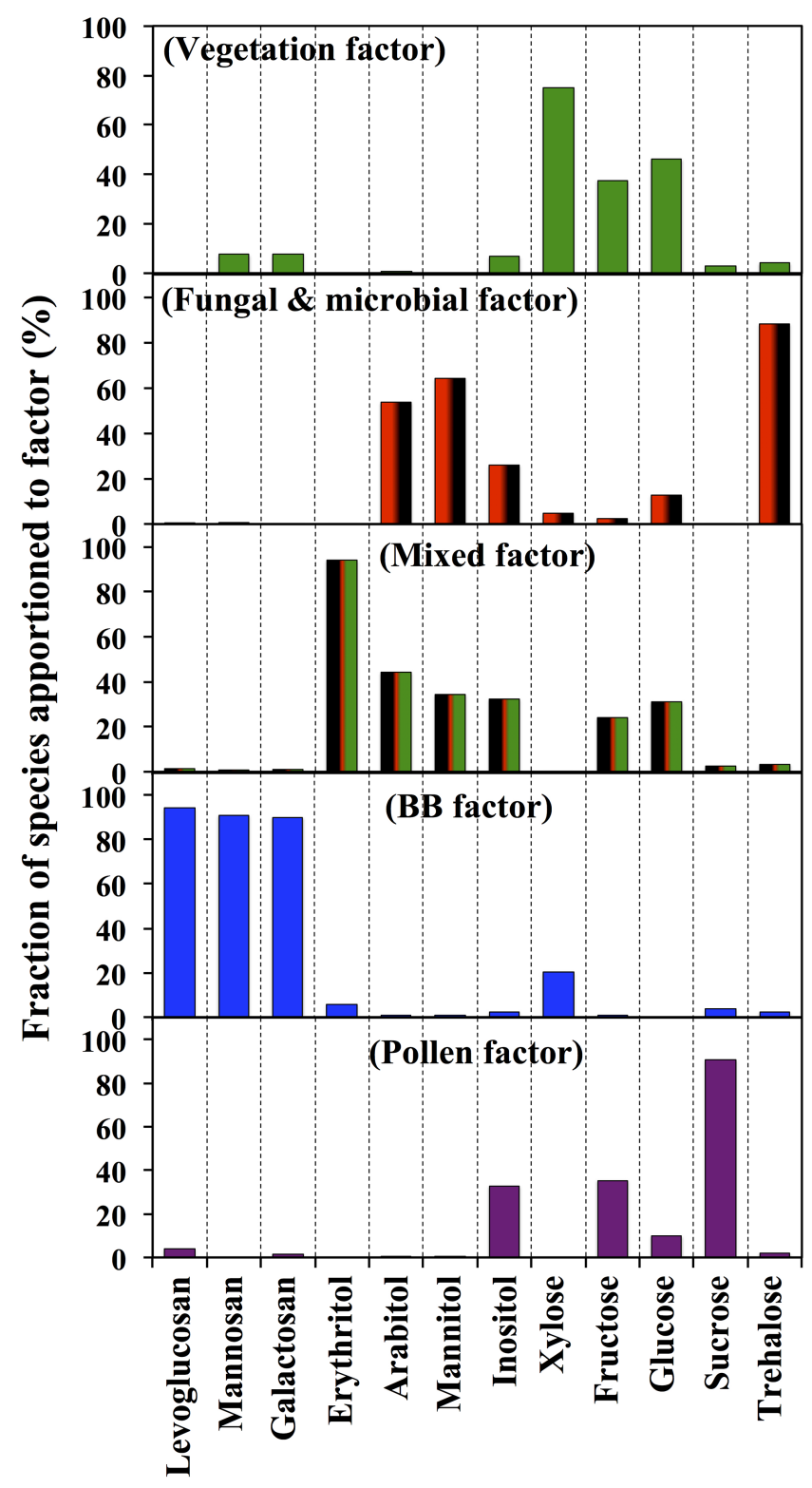

Figure 9. PMF analyses of sugar compounds in Chichijima aerosols based on the 2001-2013 data set (BB - biomass burning; mixed vegetation, fungal, and microbial sources).

PMF analysis, a total of five factors were determined to be significant to classify the sources of sugar compounds (SCs). Five factors successfully explored the source profile for the individual sugar component. Factor profiles resolved by PMF analysis are shown in Figs. 6 and 9-11, where percentages of each component summed for factors 1 to 5 are calculated to be $100 \%$.

The vegetation factor (Fig. 9) was dominated by xylose $(75 \%)$, glucose $(48 \%)$, and fructose $(36 \%)$. Xylose is significantly produced by gymnosperm and angiosperm (Cowie and Hegdes, 1984; Sjostrom, 1981). Fructose and glucose are highly water-soluble sugar species, and they are present in

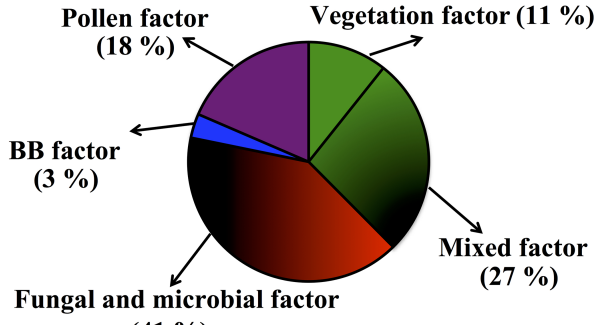

(41\%)

Figure 10. Source contributions to sugar compounds from various sources based on PMF analyses. (BB - biomass burning; mixed vegetation, fungal, and microbial sources).

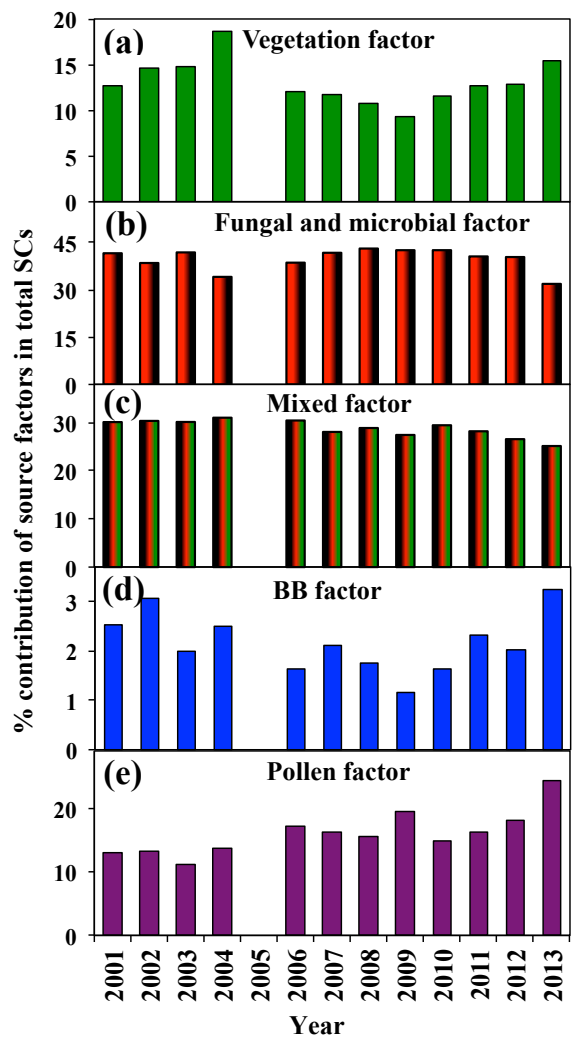

Figure 11. Annual trends in \% contributions of five source factors: (a) vegetation, (b) fungal and microbial, (c) mixed, (d) biomass burning (BB), and (e) pollen factors to SCs in Chichijima aerosols. The data of 2005 are not plotted due to limited data points.

the bark and leaves of plants (Fu et al., 2012). Glucose is the second most abundant sugar that contributed to this factor. Cowie and Hegdes (1984) reported a higher concentration of glucose in vascular plants and phytoplankton in the marine environment. The SCs emitted by vegetation during the growing season significantly contribute to the vegetation factor. In Chichijima aerosols, glucose and fructose are significant contributors in spring (Fig. 6b), summer (Fig. 6c), and autumn (Fig. 6d). Therefore, the respective factors in Fig. 6 are termed as a vegetation source for both sugar species. This 
is reasonable because plants started growing in spring and summer seasons. In autumn, leaf senescence and decay result in the emission of glucose and fructose to the atmosphere.

The fungal and microbial factor (Fig. 9) was characterized by trehalose $(88 \%)$, mannitol $(64 \%)$, and arabitol $(54 \%)$. These sugars that contribute to the fungal and microbial factor are associated with fungal spores, bacteria, and yeast (Bauer et al., 2008a; Medeiros et al., 2006; Wiemken, 1990). The three sugars are good tracers of fungal spores and microbes (Loos et al., 1994; Rogge et al., 2007). Arabitol and mannitol are produced by a large variety of fungal species (Ion et al., 2005; Medeiros et al., 2006) and are considered to be a suitable tracer for fungal and bacterial metabolic activities (Bauer et al., 2008b; Elbein et al., 1974; Rogge et al., 2007). Arabitol is strongly correlated with mannitol $(r=0.88)$, suggesting similar sources for both species (Table 2) (Elbert et al., 2007). Fungi, bacteria, and other microbes in soils are the main sources of trehalose (Graham et al., 2003; Rogge et al., 2007; Simoneit et al., 2004). An excellent correlation of trehalose with arabitol and mannitol suggested similar sources in the marine environment (Table 2) (Lewis and Smith, 1967).

Sugar alcohols have been proposed as tracers for microbes and fungal spores (Bauer et al., 2008b; Ion et al., 2005; Medeiros et al., 2006; Rogge et al., 2007). The fungal and microbial activities are considered higher during summer and autumn due to higher temperature and RH. The above discussions for the sources of arabitol, mannitol, and trehalose are well supported by the seasonal PMF analysis. Arabitol and mannitol are well contributed in summer (Fig. 6c, fungal factor and mixed factor) and autumn (Fig. 6d, fungal and vegetation factor). Correspondingly, trehalose also contributed in summer (Fig. 6c, mixed factor) and autumn (Fig. 6d, microbial factor). Therefore, significant contributions of arabitol, mannitol, and trehalose are observed during the respective seasons in Chichijima aerosols.

The mixed factor (Fig. 9) is associated with erythritol (94\%), arabitol (44\%), mannitol (34\%), inositol (32\%), glucose $(24 \%)$, and fructose $(31 \%)$. Due to the highly varied characteristics of fungi, other microbes, and plant debris, it is quite difficult to specify the particular source for individual sugar species (Percival, 1970). Arabitol and mannitol are also attributed to the vegetation (photosynthesized by mature leaves) (Burshtein et al., 2011; Pashynska et al., 2002). The contributions of arabitol and mannitol in winter (Fig. 6a, mixed factor) and spring (Fig. 6b, mixed factor) indicate sources other than fungal spores in the Chichijima aerosols because the fungal and microbial growth is less important in winter and spring compared to summer and autumn. Therefore, this factor (Fig. 9) should be associated with mixed sources from microbial and vegetational activities. Contribution of mixed sources is very likely because sugar species that are highly apportioned to the vegetation factor contribute, to some extent, to the same sources that are responsible for the fungal and microbial factor (Fig. 9).
The biomass burning (BB) factor (Fig. 9) is loaded significantly with levoglucosan $(94 \%)$, mannosan $(91 \%)$, and galactosan $(90 \%)$, and moderately with xylose $(20 \%)$. These species are associated with biomass burning (Fraser and Lakshmanan, 2000; Graham et al., 2002; Simoneit, 2002). Nolte et al. (2001) and Medeiros et al. (2006) also reported that biomass burning influenced aerosols are enriched with levoglucosan, mannosan, and galactosan. Kawamura et al. (2003) and Mochida et al. (2010) reported that biomass burning products are abundantly transported to Chichijima under the influence of westerly winds during winter and spring (Fig. 3). These results are well supported by the fact that the BB factor is associated with SCs, which are derived from biomass burning in East Asia. The seasonal PMF analysis (Fig. 6) also supports the above explanation; BB products contribute highest in winter and spring (18.8 and 6.3\%) under the influence of westerly winds, followed by summer and autumn (3.8 and $4.1 \%$ ) for total sugars in the aerosol samples collected from Chichijima Island.

The pollen factor (Fig. 9) is characterized by high loading of sucrose $(91 \%)$, fructose (35\%), and inositol (33\%); these sugar species are associated with airborne pollen sources. Previous studies have also reported that sucrose is an excellent tracer for airborne pollen grains of flowering plants (Pacini, 2000; Graham et al., 2003; Wang et al., 2008; Medeiros et al., 2006). Fructose is well correlated with inositol $(r=0.57)$, indicating a similar origin for both sugar species (Table 2). Two prominent peaks of sucrose, fructose, and inositol, which appeared in late winter to early spring or summer, also indicate a similar source of those sugars. Contributions of sucrose (pollen factor) in winter $(39.5 \%$; Fig. 6a) and spring (36\%; Fig. 6b) support that airborne pollen is a source of sucrose in Chichijima Island. The sucrose contribution (soil dust factor) in non-flowering seasons, i.e., summer (17.1\%; Fig. 6c) and autumn (8.4\%; Fig. 6d), indicates different sources of sucrose in Chichijima aerosols. According to the seasonal PMF analysis (Fig. 6), we termed additional sources of sucrose in Chichijima Island as the soil dust factor as well as the pollen factor.

As seen in Fig. 6a-d, PMF analysis for seasonal source identification indicated variable contributions of individual SCs in different seasons according to their seasonal source origin. In winter (Fig. 6a), airborne pollen $(39.5 \%)$ contributed highest, followed by vegetation, microbial, fungal (mixed) (31.2\%), biomass burning (18.8\%), and microbial $(10.5 \%)$ sources. However, in spring, vegetation, microbial, and fungal (mixed) sources $(37.2 \%)$ contributed almost equally to the airborne pollen $(36.0 \%)$, followed by vegetation $(21.2 \%)$ and biomass burning $(6.3 \%)$ sources. The vegetation, microbial, fungal (mixed) $(54.2 \%)$, fungal (25.2\%), soil particles $(17.1 \%)$, and biomass burning (3.8\%) sources are maximized in summer. Similar to summer, vegetation and fungal (mixed) sources $(71.2 \%)$ also lead to the contribution of total SCs followed by microbial $(16.4 \%)$, soil particles 
$(8.4 \%)$, and biomass burning $(4.1 \%)$ in total SCs observed in autumn for Chichijima aerosols.

Overall, average contributions of each factor to measured SCs as resolved by the PMF analyses are shown in Fig. 10. The fungal and microbial factor accounts for $41 \%$ of total $\mathrm{SCs}$ measured. The emission from microbes including fungal spores was found as a dominant contributor to total SCs. The mixed factor $(27 \%)$ indicates a common involvement of fungal, microbial, and vegetation sources. Figure 11 shows annual trends in percentage contributions of five source factors to SCs in Chichijima aerosols. The fungal and microbial factor and the mixed factor contributed higher than other sources to SCs during 2001 to 2013. However, no clear trends in annual percentage contributions were observed for both source factors during the 13-year study period. The sugar species assigned as pollen tracers were found to contribute $18 \%$ in the pollen factor. Vegetation accounts for $11 \%$ of total SCs, indicating less emission from vegetation as compared to fungi and microbes. As indicated by the BB factor, biomass burning source contributes only $3 \%$ of total SCs.

Interestingly, we found an increasing trend in percentage contribution of vegetation, pollen, and BB factors to SCs in 2006 to 2013 (see Fig. 11). Sugar components, which are contributed from pollen (sucrose, fructose, and inositol), vegetation (glucose and fructose), and biomass burning sources (levoglucosan, galactosan, and mannosan), also show a similar increasing trend for the period of 2006 to 2013 (Fig. 7). The increased annual trends of $\mathrm{BB}$ and pollen factors might be due to an enhanced long-range transport of airborne pollen and biomass burning products from the Asian continent to the western North Pacific under the influence of strong westerly winds.

\section{Summary and conclusions}

We reported 13 years of temporal, seasonal, and decadal trends of sugar compounds (SCs) measured in the aerosol samples collected at Chichijima Island in the western North Pacific, an outflow region of Asian aerosols. The high abundances of total SCs and primary sugars are found during summer, whereas sugar alcohols are almost equally distributed during summer and autumn. The seasonal distributions of arabitol, mannitol, and trehalose are strongly influenced by long-range atmospheric transport of bioaerosols associated with microbes such as fungi and bacteria and their metabolic activities under the influences of westerly winds and favorable meteorological conditions, including high RH and temperature in summer and autumn. Seasonal variation of sucrose is controlled by both locally emitted and long-range transported pollen from East Asia to the western North Pacific during spring bloom periods. Conversely, the increased concentrations of sucrose and fructose during summer may be caused by local vegetation activity and possibly by the long-range transport of plant root-associated soil dust parti- cles from East and Southeast Asia. PMF analysis indicated specific sources of individual SCs during different seasons. The results clearly separated biogenic emissions into two parts as vegetation and microbes, including fungal species. The emissions from vegetation, pollen, and microbial activities contributed about $97 \%$ of total measured SCs, with the remaining fraction being derived from biomass burning activities.

The concentration and seasonal variations of SCs at Chichijima Island are well regulated by atmospheric circulations; i.e., the westerly winds passing from the Asian continent during winter and spring and trade winds originated from the central Pacific Ocean during summer and autumn dominate over Chichijima Island in the western North Pacific. Meteorological parameters also significantly affect the concentrations and seasonal variation of SCs over Chichijima. Based on a decadal observation at Chichijima, we conclude that drastic increases in the concentrations of sugar alcohols and primary sugars during 2001-2003 and 20102013 can be caused by an enhanced atmospheric transport of bioaerosols from East Asia to the western North Pacific.

Sugar components (SCs) are an important part of the composition of organic aerosols worldwide and they are recognized as a significant factor affecting air quality and possibly climate. The outcomes of the study of SCs over 13 years at Chichijima Island have an implication for global radiative forcing by scattering or absorbing light and also the activity of cloud condensation nuclei (CCN) in the western North Pacific that have a high sensitivity to global climate change due to the outflow region of the Asian dust and bioaerosols. The NASA Global Climate Change (http://climate.nasa.gov/ vital-signs/global-temperature/) has reported a continuous increase in the global land-ocean temperature. The increasing annual trends in percentage contribution of vegetation factor to SCs suggested significantly increased local vegetation activity in Chichijima Island from 2006 to 2013, which could be related to recent global warming especially in the western North Pacific region.

Data availability. The data for this paper are available upon request from the corresponding author (Kimitaka Kawamura, kkawamura@isc.chubu.ac.jp). Meteorological data including ambient temperature, relative humidity, wind speed, temperature, and precipitation were obtained from the Japan Meteorological Agency (http://www.jma.go.jp).

Competing interests. The authors declare that they have no conflict of interest.

Acknowledgements. We acknowledge the financial support by Japan Society for the Promotion of Science (JSPS) through grant-in-aid nos. 19204055 and 24221001 . The authors gratefully appreciate the NOAA Air Resources Laboratory (ARL) for 
the provision of the HYSPLIT transport and dispersion model (http://www.ready.noaa.gov).

Edited by: Jason Surratt

Reviewed by: two anonymous referees

\section{References}

Andrews, J. T., Mode, W. N., and Davis, P. T.: Holocene climate based on pollen transfer-functions, Eastern Canadian Arctic, Arct. Alp. Res., 12, 41-64, 1980.

Baker, H. G., Baker, I., and Hodges, S. A.: Sugar composition of nectars and fruits consumed by birds and bats in the tropics and subtropics, Biotropica, 30, 559-586, 1998.

Bauer, H., Schueller, E., Weinke, G., Berger, A., Hitzenberger, R., Marr, I. L., and Puxbaum, H.: Significant contributions of fungal spores to the organic carbon and to the aerosol mass balance of the urban atmospheric aerosol, Atmos. Environ., 42, 5542-5549, 2008a.

Bauer, H., Claeys, M., Vermeylen, R., Schueller, E., Weinke, G., Berger, A., and Puxbaum, H.: Arabitol and mannitol as tracers for the quantification of airborne fungal spores, Atmos. Environ., 42, 588-593, 2008b.

Bendle, J., Kawamura, K., Yamazaki, K., and Niwai, T.: Latitudinal distribution of terrestrial lipid biomarkers and n-alkane compound-specific stable carbon isotope ratios in the atmosphere over the western Pacific and Southern Ocean, Geochim. Cosmochim. Ac., 71, 5934-5955, 2007.

Bieleski, R. L.: Onset of phloem export from senescent petals of Daylily, Plant Physiol., 109, 557-565, 1995.

Bourgeois, J. C., Gajewski, K., and Koerner, R. M.: Spatial patterns of pollen deposition in arctic snow, J. Geophys. Res., 106, 52555265, 2001.

Bremer, G. B.: Lower marine fungi (Labyrinthulomycetes) and the decay of mangrove leaf-litter, Hydrobiologia, 304, 243-245, 1995.

Brown, J. K. M. and Hovmoller, M. S.: Epidemiology - Aerial dispersal of pathogens on the global and continental scales and its impact on plant disease, Science, 297, 537-541, 2002.

Burshtein, N., Lang-Yona, N., and Rudich, Y.: Ergosterol, arabitol and mannitol as tracers for biogenic aerosols in the eastern Mediterranean, Atmos. Chem. Phys., 11, 829-839, https://doi.org/10.5194/acp-11-829-2011, 2011.

Bzdusek P. A., Christensen, E. R., Lee, C. M., Pakadeesusuk, U., Freedman, D. C.: PCB congeners and dechlorination in sediments of Lake Hartwell, South Carolina, determined from cores collected in 1987 and 1988, Environ. Sci. Technol., 40, 109-119, 2006.

Campbell, I. D., McDonald, K., Flannigan, M., and Kringayark, J.: Long-distance transport of pollen into the Arctic, Nature, 399, 29-30, 1999.

Carvalho, A., Pio, C., and Santos, C.: Water-soluble hydroxylated organic compounds in German and Finnish aerosols, Atmos. Environ., 37, 1775-1783, 2003.

Chen, J., Kawamura, K., Liu, C. Q., and Fu, P. Q.: Long-term observations of saccharides in remote marine aerosols from the western North Pacific: A comparison between 1990-1993 and 20062009 periods, Atmos. Environ., 67, 448-458, 2013.
Cowie, G. L. and Hedges, J. I.: Carbohydrate sources in a coastal marine-environment, Geochim. Cosmochim. Ac., 48, 20752087, 1984.

Dahlman, L., Persson, J., Nasholm, T., and Palmqvist, K.: Carbon and nitrogen distribution in the green algal lichens Hypogymnia physodes and Platismatia glauca in relation to nutrient supply, Planta, 217, 41-48, 2003.

Duce, R. A., Unni, C. K., Ray, B. J., Prospero, J. M., and Merrill, J. T.: Long-range atmospheric transport of soil dust from Asia to the tropical North Pacific: temporal variability, Science, 209, 1522-1524, 1980.

Elbein, A. D.: The metabolism of $\alpha, \alpha$-trehalose, Adv. Carboh. Chem. Biochem., 30, 227-256, 1974.

Elbert, W., Taylor, P. E., Andreae, M. O., and Pöschl, U.: Contribution of fungi to primary biogenic aerosols in the atmosphere: wet and dry discharged spores, carbohydrates, and inorganic ions, Atmos. Chem. Phys., 7, 4569-4588, https://doi.org/10.5194/acp-74569-2007, 2007.

Elliot, S., Blake, D. R., Duce, R. A., Lai, C. A., McCreary, I., McNair, L. A., Rowland, F. S., Russell, A. G., Streit, G. E., and Turco, R. P.: Motorization of China implies changes in pacific air chemistry and primary production, Geophys. Res. Lett., 24, 2671-2674, 1997.

Filippo, P. D., Pomata, D., Riccardi, C., Buiarelli, F., and Perrino, C.: Fungal contribution to size-segregated aerosol measured through biomarkers, Atmos. Environ., 64, 132-140, 2013.

Fraser, M. P. and Lakshmanan, K.: Using levoglucosan as a molecular marker for the long-range transport of biomass combustion aerosols, Environ. Sci. Technol., 34, 4560-4564, 2000.

Fu, P. Q., Kawamura, K., Kobayashi, M., and Simoneit, B. R. T.: Seasonal variations of sugars in atmospheric particulate matter from Gosan, Jeju Island: Significant contributions of airborne pollen and Asian dust in spring, Atmos. Environ., 55, 234-239, 2012.

Fuzzi, S., Decesari, S., Facchini, M. C., Cavalli, F., Emblico, L., Mircea, M., Andreae, M. O., Trebs, I., Hoffer, A., Guyon, P., Artaxo, P., Rizzo, L. V., Lara, L. L., Pauliquevis, T., Maenhaut, W., Raes, N., Chi, X. G., Mayol-Bracero, O. L., SotoGarcia, L. L., Claeys, M., Kourtchev, I., Rissler, J., Swietlicki, E., Tagliavini, E., Schkolnik, G., Falkovich, A. H., Rudich, Y., Fisch, G., and Gatti, L. V.: Overview of the inorganic and organic composition of size-segregated aerosol in Rondonia, Brazil, from the biomass-burning period to the onset of the wet season, J. Geophys. Res.-Atmos., 112, D01201, https://doi.org/10.1029/2005jd006741, 2007.

Graham, B., Mayol-Bracero, O. L., Guyon, P., Roberts, G. C., Decesari, S., Facchini, M. C., Artaxo, P., Maenhaut, W., Koll, P., and Andreae, M. O.: Water-soluble organic compounds in biomass burning aerosols over Amazonia - 1. Characterization by NMR and GC-MS, J. Geophys. Res.-Atmos., 107, 8047, https://doi.org/10.1029/2001jd000336, 2002.

Graham, B., Guyon, P., Taylor, P. E., Artaxo, P., Maenhaut, W., Glovsky, M. M., Flagan, R. C., and Andreae, M. O.: Organic compounds present in the natural Amazonian aerosol: Characterization by gas chromatography-mass spectrometry, J. Geophys. Res.-Atmos., 108, 4766, https://doi.org/10.1029/2003jd003990, 2003. 
Griffin, D. W.: Atmospheric movement of microorganisms in clouds of desert dust and implications for human health, Clin. Microbiol. Rev., 20, 459-477, 2007.

Griffin, D. W., Garrison, V. H., Herman, J. R., and Shinn, E. A.: : African desert dust in the Caribbean atmosphere: Microbiology and public health, Aerobiologia, 17, 203-213, 2001.

Griffin, D. W., Kellogg, C. A., Garrison, V. H., Lisle, J. T., Borde, T. C., and Shinn, E. A.: Atmospheric microbiology in the northern Caribbean during African dust events, Aerobiologia, 19, 143157, 2003.

Hackl, E., Bachmann, G., and Zechmeister-Boltenstern, S.: Soil microbial biomass and rhizosphere effects in natural forest stands, Phyton.-Ann. Rei. Bot. A, 40, 83-90, 2000.

Hader, J. D., Wright, T. P., and Petters, M. D.: Contribution of pollen to atmospheric ice nuclei concentrations, Atmos. Chem. Phys., 14, 5433-5449, https://doi.org/10.5194/acp-145433-2014, 2014.

Hicks, S., Tinsley, H., Huusko, A., Jensen, C., Hättestrand, M., Gerasimides, A., and Kvavadze, E.: Some comments on spatial variation in arboreal pollen deposition: First records from the Pollen Monitoring Programme (PMP), Rev. Palaeobot. Palynol., 117, 183-194, 2001.

Hirst J. M., Stedman, O. J., and Hogg, W. H.: Long-distance spore transport: Methods of measurement, vertical spores profile and the detection of immigrant spores, J. Gen. Microbiol., 48, 329355, 1967.

Hjelmroos, M. and Franzen, L. G.: Implications or recent long distance pollen transport events for the interpretation of fossil pollen records in Fennoscandia, Rev. Palaeobot. Palynol., 82, 175-189, 1994. Hua, NP., Kobayashi, F., Iwasaka, Y., Shi, G. Y., and Naganuma, T.: Detailed identification of desert-originated bacteria carried by Asian dust storms to Japan, Aerobiologia, 23, 291298, 2007.

Hyde, K. D., Jones, E. B. G., Leano, E., Pointing, S. B., Poonyth, A. D., and Vrijmoed, L. L. P.: Role of fungi in marine ecosystems, Biodivers. Conserv., 7, 1147-1161, 1998.

Ibrahim, M., Rabah, A. B., Liman, B., and Ibrahim, N. T.: Effect of temperature and relative humidity on the growth of Helminthosporium fulvum, Nigerian J. Basic Appli. Sci., 19, 127-129, 2011.

Ion, A. C., Vermeylen, R., Kourtchev, I., Cafmeyer, J., Chi, X., Gelencsér, A., Maenhaut, W., and Claeys, M.: Polar organic compounds in rural $\mathrm{PM}_{2.5}$ aerosols from K-puszta, Hungary, during a 2003 summer field campaign: Sources and diel variations, Atmos. Chem. Phys., 5, 1805-1814, https://doi.org/10.5194/acp-51805-2005, 2005.

Iwasaka, Y., Minoura, H., and Nagaya, K.: The transport and special scale of Asian dust-storm clouds: a case study of the dust-storm event of April 1979, Tellus, 35B, 189-196, 1983.

Jaffe, D. A., Anderson, T., Covert, D., Kotchenruther, R., Trost, B., Danielson, J., Simpson, W., Berntsen, T., Karlsdottir, S., Blake, D., Harris, J., Carmichael, G., and Uno, I.: Transport of Asian air pollution to North America, Geophys. Res. Lett., 26, 711-714, 1999.

Jaffe, D. A., McKendry, I., Anderson, T., and Price, H.: Six "new" episodes of trans-Pacific transport of air pollutants, Atmos. Environ., 37, 391-404, 2003.

Jaffe, D. A., Mahura, A., Kelley, J., Atkins, J., Novelli, P. C., and Merrill, J.: Impact of Asian Emissions on the Remote North
Pacific Atmosphere: Interpretation of CO Data from Shemya, Guam, Midway and Mauna Loa, J. Geophys. Res., 23, 2862728636, 1997.

Jeon, E. M., Kim, H. J., Jung, K., Kim, J. H., Kim, M. Y., Kim, Y. P., and Ka, J. O.: Impact of Asian dust events on airborne bacterial community assessed by molecular analyses, Atmos. Environ., 45, 4313-4321, 2011.

Jia, Y. and Fraser, M.: Characterization of saccharides in sizefractionated ambient particulate matter and aerosol sources: the contribution of primary biological aerosol particles (PBAPs) and soil to ambient particulate matter, Environ. Sci. Technol., 45, 930-936, 2011.

Jia, Y. L., Clements, A. L., and Fraser, M. P.: Saccharide composition in atmospheric particulate matter in the southwest US and estimates of source contributions, J. Aerosol Sci., 41, 62-73, 2010.

Jones, E. B. G. and Mitchell, J. I.: Biodiversity of marine fungi, In Biodiversity: International Biodiversity Seminar, edited by: Cimerman, A. and Gunde-Cimerman, N., 31-42, Ljubljana: National Inst. Chemistry and Slovenia National Commission for UNESCO, 1996.

Juntto, S. and Paatero, P.: Analysis of daily precipitation data by positive matrix factorization, Environmetrics, 5, 127-144, 1994.

Kanakidou, M., Seinfeld, J. H., Pandis, S. N., Barnes, I., Dentener, F. J., Facchini, M. C., Van Dingenen, R., Ervens, B., Nenes, A., Nielsen, C. J., Swietlicki, E., Putaud, J. P., Balkanski, Y., Fuzzi, S., Horth, J., Moortgat, G. K., Winterhalter, R., Myhre, C. E. L., Tsigaridis, K., Vignati, E., Stephanou, E. G., and Wilson, J.: Organic aerosol and global climate modelling: a review, Atmos. Chem. Phys., 5, 1053-1123, https://doi.org/10.5194/acp-5-10532005, 2005.

Kawamura, K., Ishimura, Y., and Yamazaki, K.: Four years' observations of terrestrial lipid class compounds in marine aerosols from the western North Pacific, Global Biogeochem. Cycles, 17, 1003, https://doi.org/10.1029/2001gb001810, 2003.

Kim, V. K. and Xiao, C. L.: Influence of culture media and environmental factors on mycelial growth and picnidial production of Sphaeropsis pyriputrescens, Mycologia, 97, 25-32, 2005.

Kohlmeyer, J. and Volkmann-Kohlmeyer, B.: Illustrated key to the filamentous fungi, Bot. Mar. 34, 1-61, 1991.

Lewis, D. H. and Smith, D. C.: Sugar alcohols (polyols) in fungi and green plants. I. Distribution physiology and metabolism, New Phytologist, 66, 143-184, 1967.

Loos, H., Kramer, R., Sahm, H., and Sprenger, G. A.: Sorbitol promotes growth of zymomonas mobilis in environments with high concentrations of sugar: evidence for a physiological function of glucose-fructose oxidoreductase in osmoprotection, J. Bacteriol., 176, 7688-7693, 1994.

Lu, J., Jiang, P., Wu, L., and Chang, A. C.: Assessing soil quality data by positive matrix factorization, Geoderma, 145, 259-266, 2008.

Ma, S. X., Wang, Z. Z., Bi, X. H., Sheng, G. Y., and Fu, J. M.: Composition and source of saccharides in aerosols in Guangzhou, China, Chinese Sci. Bull., 54, 4500-4506, 2009.

Makra, L., Santa, T., Matyasovszky, I., Damialis, A., Karatzas, K., Bergmann, K. C., and Vokou, D.: Airborne pollen in three European cities: Detection of atmospheric circulation pathways by applying three-dimensional clustering of back- 
ward trajectories, J. Geophys. Res.-Atmos., 115, D24220, https://doi.org/10.1029/2010jd014743, 2010.

Malik, V. K. and Singh, S.: Effect of temperature and relative humidity on teliospore germination in Ustilago hordei, J. Mycol. Plant Pathol., 34, 410-411, 2004.

Martin, S. T., Andreae, M. O., Artaxo, P., Baumgardner, D, Chen, Q., Goldstein, A. H., Guenther, A., Heald, C. L., Bracero, O. L. M., McMurry, P. H., Pauliquevis, T., Pöschl, U., Prather, K. A., Roberts, G. C., Saleska, S. R., Dias, M. A. S., Spracklen, D. V., Swietlicki, E., and Trebs, I.: Sources and Properties of Amazonian Aerosol Particles, Rev. Geophys., 48, RG2002, https://doi.org/10.1029/2008rg000280, 2010.

Medeiros, P. M., Conte, M. H., Weber, J. C., and Simoneit, B. R. T.: Sugars as source indicators of biogenic organic carbon in aerosols collected above the Howland Experimental Forest, Maine, Atmos. Environ., 40, 1694-1705, 2006.

Medeiros, P. M. and Simoneit, B. R. T.: Source profiles of organic compounds emitted upon combustion of green vegetation from temperate climate forests, Environ. Sci. Technol., 42, 8310 8316, 2008.

Miguel, A. G., Taylor, P. E., House, J., Glovsky, M. M., and Flagan, R. C.: Meteorological influences on respirable fragment release from Chinese elm pollen, Aerosol Sci. Technol., 40, 690-696, 2006

Mims, S. A. and Mims, F. M.: Fungal spores are transported long distances in smoke from biomass fires, Atmos. Environ., 38, 651-655, 2003.

Miyazaki, Y., Jung, J., Fu, P., Mizoguchi, Y., Yamanoi, K., and Kawamura, K.: Evidence of formation of submicrometer water-soluble organic aerosols at a deciduous forest site in northern Japan in summer, J. Geophys. Res., 117, D19213, https://doi.org/10.1029/2012JD018250, 2012.

Mochida, M., Kawabata, A., Kawamura, K., Hatsushika, H., and Yamazaki, K.: Seasonal variation and origins of dicarboxylic acids in the marine atmosphere over the western North Pacific, J. Geophys. Res. Atmos., 108, 4193, https://doi.org/10.1029/2002jd002355, 2003a.

Mochida, M., Kawamura, K., Umemoto, N., Kobayashi, M., Matsunaga, S., Lim, H. J., Turpin, B. J., Bates, T. S., and Simoneit, B. R. T.: Spatial distributions of oxygenated organic compounds (dicarboxylic acids, fatty acids, and levoglucosan) in marine aerosols over the western Pacific and off the coast of East Asia: Continental outflow of organic aerosols during the ACE-Asia campaign, J. Geophys. Res.-Atmos., 108, 8638, https://doi.org/10.1029/2002jd003249, 2003b.

Mochida, M., Kawamura, K., Fu, P. Q., and Takemura, T.: Seasonal variation of levoglucosan in aerosols over the western North Pacific and its assessment as a biomass-burning tracer, Atmos. Environ., 44, 3511-3518, 2010.

Morris, C. E., Georgakopoulos, D. G., and Sands, D. C.: Ice nucleation active bacteria and their potential role in precipitation, $\mathrm{J}$. Phys. IV, 121, 87-103, 2004.

Nakagiri, A., Newell, S. Y., Ito, T., and Tan, T. K.: Biodiversity and ecology of the oomycetous fungus, Halophytophthora, In Biodiversity and the Dynamics of Ecosystems, DIWPA series. Vol. 1, edited by: Turner, I. M., Diong, C. H., Lim, S. S. L., and Ng, P. K. L., 273-280, Tokyo: International Network for DIVERSITAS in Western Pacific and Asia, 1996.
Nolte, C. G., Schauer, J. J., Cass, G. R., and Simoneit, B. R. T.: Highly polar organic compounds present in wood smoke and in the ambient atmosphere, Environ. Sci. Technol., 35, 1912-1919, 2001.

Paatero, P. and Tapper, U.: Positive Matrix Factorization - a Nonnegative Factor Model with Optimal Utilization of ErrorEstimates of Data Values, Environmetrics, 5, 111-126, 1994.

Paatero, P., Hopke, P. K., Song, X. H., and Ramadan, Z.: Understanding and controlling rotations in factor analytic models, Chemom. Intell. Lab. Syst., 60, 253-264, 2002.

Pacini, E.: From anther and pollen ripening to pollen presentation, Plant Syst. Evol., 222, 19-43, 2000.

Pashynska, V., Vermeylen, R., Vas, G., Maenhaut, W., and Claeys, M.: Development of a gas chromatographic/ion trap mass spectrometric method for the determination of levoglucosan and saccharidic compounds in atmospheric aerosols. Application to urban aerosols, J. Mass Spectrom., 37, 1249-1257, 2002.

Pavuluri, C. M., Kawamura, K., Tachibana, E., and Swaminathan, T.: Elevated nitrogen isotope ratios of tropical Indian aerosols from Chennai: Implication for the origins of aerosol nitrogen in South and Southeast Asia, Atmos. Environ., 44, 3597-3604, 2010.

Polissar A. V., Hopke, P. K., Paatero, P., Kaufmann, Y. J., Hall, D. K., Bodhaine, B. A., Dutton, E. G., and Harris, J. M.: The aerosol at Barrow, Alaska: long-term trends and source locations, Atmos. Environ., 33, 2441-2458, 1999.

Prospero, J. M. and Savoie, D. L.: Effect of continental sources of nitrate concentrations over the Pacific Ocean, Nature, 339, 687689, 1989.

Prospero, J. M., Blades, E., Mathison, G., and Naidu, R.: Interhemispheric transport of viable fungi and bacteria from Africa to the Caribbean with soil dust, Aerobiologia, 21, 1-19, 2005.

Rogge, W. F., Medeiros, P. M., and Simoneit, B. R. T.: Organic marker compounds for surface soil and fugitive dust from open lot dairies and cattle feedlots, Atmos. Environ., 40, 27-49, 2006.

Rogge, W. F., Medeiros, P. M., and Simoneit, B. R. T.: Organic marker compounds in surface soils of crop fields from the San Joaquin Valley fugitive dust characterization study, Atmos. Environ., 41, 8183-8204, 2007.

Rousseau, D.-D., Schevin, P., Ferrier, J., Jolly, D., Andreasen, T., Ascanius, S. E., Hendriksen, S. E., and Poulsen, U. Long-distance pollen transport from North America to Greenland in spring, J. Geophys. Res.-Biogeo., 113, G02013, https://doi.org/10.1029/2007jg000456, 2008.

Rousseau, D.-D., Duzer, D., Etienne, J.-L., Cambon, G., Jolly, D., Ferrier, J., and Schevin, P.: Pollen record of rapidly changing air trajectories to the North Pole, J. Geophys. Res., 109, D06116, https://doi.org/10.1029/2003JD003985, 2004.

Rousseau, D.-D., Schevin, P., Duzer, D., Cambon, G., Ferrier, J., Jolly, D., and Poulsen, U.: New evidence of long distance pollen transport to southern Greenland in late Spring, Rev. Palaeobot. Palynol., 141, 277-286, 2006.

Schmidl, C., Bauer, H., Dattler, A., Hitzenberger, R., Weissenboeck, G., Marr, I. L., and Puxbaum, H.: Chemical characterisation of particle emissions from burning leaves, Atmos. Environ., 42, 9070-9079, 2008.

Seinfeld, J. H., Carmichael, G. R., Arimoto, R., Conant, W. C., Brechtel, F. J., Bates, T. S., Cahill, T. A., Clarke, A. D., Doherty, S. J., Flatau, P. J., Huebert, B. J., Kim, J., Markowicz, K. M., 
Quinn, P. K., Russell, L. M., Russell, P. B., Shimizu, A., Shinozuka, Y., Song, C. H., Tang, Y., Uno, I., Vogelmann, A. M., Weber, R. J., Woo, J. H., and Zhang, H. Y.: ACE-ASIA - Regional climatic and atmospheric chemical effects of Asian dust and pollution, Am. Meteor. Soc., 85, 367-380, 2004.

Sharma, R. and Rajak, R. C.: Keratinophilic fungi: Nature's keratin degrading machines, Resonance, 8, 28-30, 2003.

Simoneit, B. R. T.: Biomass burning - A review of organic tracers for smoke from incomplete combustion, Appl. Geochem., 17, 129-162, 2002.

Simoneit, B. R. T.: Biomarkers (molecular fossils) as geochemical indicators of life, Adv. Space. Res., 33, 1255-1261, 2004.

Simoneit, B. R. T. and Elias, V. O.: Organic tracers from biomass burning in atmospheric particulate matter over the ocean, Mar. Chem., 69, 301-312, 2000.

Simoneit, B. R. T., Elias, V. O., Kobayashi, M., Kawamura, K., Rushdi, A. I., Medeiros, P. M., Rogge, W. F., and Didyk, B. M.: Sugars-dominant water-soluble organic compounds in soils and characterization as tracers in atmospheric particulate matter, Environ. Sci. Technol., 38, 5939-5949, 2004a.

Simoneit, B. R. T., Kobayashi, M., Mochida, M., Kawamura, K., Lee, M., Lim, H. J., Turpin, B. J., and Komazaki, Y.: Composition and major sources of organic compounds of aerosol particulate matter sampled during the ACE-Asia campaign, J. Geophys. Res.-Atmos., 109, D19S10, https://doi.org/10.1029/2004jd004598, 2004b.

Slinn, S. A. and Slinn, W. G. N.: Predictions for particle deposition on natural waters, Atmos. Environ., 14, 1013-1016, 1980.

Soonthornnonda, P. and Christensen, E. R.: Source apportionment of pollutants and flows of combined sewer wastewater, Water Res., 42, 1989-1998, 2008.

Sosnoskie, L. M., Webster, T. M., Dales, D., Rains, G. C., Grey, T. L., and Culpepper, A. S.: Pollen grain size, density, and settling velocity for Palmer amaranth (Amaranthus palmeri), Weed Sci., 57, 404-409, https://doi.org/10.1614/WS-08-157.1, 2009.

Speranza, A., Calzoni, G. L., and Pacini, E.: Occurrence of monoor disaccharides and polysaccharide reserves in mature pollen grains, Sex. Plant Reprod., 10, 110-115, 1997.

Sullivian, A. P., Frank, N., Kenski Jr., D. M., and Collett, J. L.: Application of high-performance anion-exchange chromatographypulsed amperometric detection for measuring carbohydrates in routine daily filter samples collected by a national network: 2 . Examination of sugar alcohols/polyols, sugars, and anhydrosugars in the upper Midwest, J. Geophys. Res., 116, D08303, https://doi.org/10.1029/2010JD014169, 2011.

Talbot, R. W., Dibb, J. E., Lefer, B. L., Bradshaw, J. D., Sandholm, S. T., Blake, D. R., Blake, N. J., Sachse, G. W., Collins Jr., J. E., Heikes, B. G., Merrill, J. T., Gregory, G. L., Anderson, B. E., Singh, H. B., Thornton, D. C., Bandy, A. R., and Pueschel, R. F.: Chemical characteristics of continental outflow from Asia to the troposphere over the western Pacific Ocean during FebruaryMarch 1994: Results from PEM-West B, J. Geophys. Res., 102, 28255-28274, 1997.

Tominaga, S., Matsumoto, K., Kaneyasu, N., Shigihara, A., Katono, K., and Igawa, N.: Measurements of particulate sugars at urban and forested suburban sites, Atmos. Environ. 45, 2335-2339, 2011.

Uno, I., Eguchi, K., Yumimoto, K., Takemura, T., Shimizu, A., Uematsu, M., Liu, Z. Y., Wang, Z. F., Hara, Y., and Sugimoto, N.:
Asian dust transported one full circuit around the globe, Nat. Geosci., 2, 557-560, 2009.

Verma, S. K., Kawamura, K., Chen, J., Fu, P. Q., and Zhu, C.: Thirteen years observation of biomass-burning organic tracers over Chichijima Island in the western North Pacific: An outflow region of Asian aerosols, J. Geophys. Res. Atmos., 120, 41554168, https://doi.org/10.1002/2014JD022224, 2015.

Wan, E. C. H. and Yu, J. Z.: Analysis of sugars and sugar polyols in atmospheric aerosols by chloride attachment in liquid chromatography/negative ion electrospray mass spectrometry, Environ. Sci. Technol., 41, 2459-2466, 2007.

Wang, G. H., Chen, C. L., Li, J. J., Zhou, B. H., Xie, M. J., Hu, S. Y., Kawamura, K., and Chen, Y.: Molecular composition and size distribution of sugars, sugar-alcohols and carboxylic acids in airborne particles during a severe urban haze event caused by wheat straw burning, Atmos. Environ., 45, 2473-2479, 2011.

Wang, G. H., Kawamura, K., and Lee, M.: Comparison of organic compositions in dust storm and normal aerosol samples collected at Gosan, Jeju Island, during spring 2005, Atmos. Environ., 43, 219-227, 2009.

Wright, T. P., Hader, J. D., McMeeking, G. R., and Petters, M. D.: High relative humidity as a trigger for widespread release of ice nuclei, Aerosol Sci. Tech., 48, 11, https://doi.org/10.1080/02786826.2014.968244, 2014.

Wright, T. P., Hader, J. D., McMeeking, G. R., and Peters, M. D.: High relative humidity as a trigger for widespread release of ice Nuclei, Anton. Leeuw. Int. J. G., 58, 209-217, 1990.

Xie Y. and Berkowitz, C. M.: The use of positive matrix factorization with conditional probability functions in air quality studies: an application to hydrocarbon emissions in Houston, Texas, Atmos. Environ., 40, 3070-3091, 2006.

Xu, W. Y., Zhao, C. S., Ran, L., Deng, Z. Z., Liu, P. F., Ma, N., Lin, W. L., Xu, X. B., Yan, P., He, X., Yu, J., Liang, W. D., and Chen, L. L.: Characteristics of pollutants and their correlation to meteorological conditions at a suburban site in the North China Plain, Atmos. Chem. Phys., 11, 4353-4369, https://doi.org/10.5194/acp-11-4353-2011, 2011.

Yamaguchi, N., Ichijo, T., Sakotani, A., Baba, T., and Nasu, M.: Global dispersion of bacterial cells on Asian dust, Sci. Rep., 2, 525, https://doi.org/10.1038/srep00525, 2012.

Yang, Y. H., Chan, C. Y., Tao, J., Lin, M., Engling, G., Zhang, Z. S., Zhang, T., and Su, L.: Observation of elevated fungal tracers due to biomass burning in the Sichuan Basin at Chengdu City, China, Sci. Total Environ., 431, 68-77, 2012.

Yttri, K. E., Dye, C., and Kiss, G.: Ambient aerosol concentrations of sugars and sugar-alcohols at four different sites in Norway, Atmos. Chem. Phys., 7, 4267-4279, https://doi.org/10.5194/acp7-4267-2007, 2007.

Zhang, T., Engling, G., Chan, C.-Y., Zhang, Y.-N., Zhang, Z.S., Lin, M., Sang, X.-F., Li, Y. D., and Li, Y.-S.: Contribution of fungal spores to particulate matter in a tropical rainforest, Environ. Res. Lett., 5, https://doi.org/10.1088/17489326/5/2/024010, 2010.

Zhou, L., Kim, E., Hopke, P. K., Stanier, C. O., and Pandis, S.: Advanced factor analysis on Pittsburgh particle size-distribution data special issue of aerosol science and technology on findings from the fine particulate matter supersites program, Aerosol Sci. Technol., 38, 118-132, 2004. 
Zhu, C., Kawamura, K., and Kunwar, B.: Organic tracers of primary biological aerosol particles at subtropical Okinawa Island in the western North Pacific Rim, J. Geophys. Res.-Atmos., 120, 55045523,2015 